\title{
مقاصد القرآن في إحياء قِيم الإنسان الحضارية
}

\author{
نور الدين بن مختار الخادمي*
الملخص
مقاصد القرآن الكريم هي أبعاده الغائية والمصحلية، وأسراره الحكمية التعليلية، وآفاقه في إقامة الحضارة وترشيد

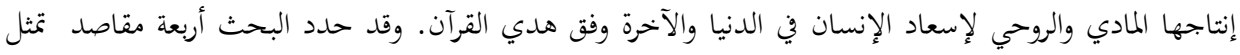

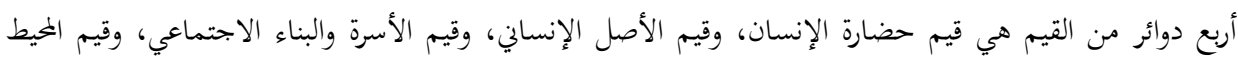
البيئي. \\ الكلمات المفتاحية: مقاصد القرآن، قيم الحضارة الإنسانية، دوائر القيم.
}

\section{The Intents of the Gracious Qur'an in Reviving Values of Human Civilization \\ Nour Al-Deen Ibn Mukhtar Al-Khadimi}

\begin{abstract}
The Intents of the Glorious Quran are its teleological and beneficial dimensions, its wise and explanatory mysteries, and its prospects in establishing civilization and rationalizing its material and spiritual production for the benefits of Man in this world and the hereafter within the guidance of the Qur'an. The paper identifies four intents that represent four areas of values: values of human civilization, values of human origin, values of family and social construction, and environmental values.
\end{abstract}

Keywords: Qur'anic intents, Values of human civilization, Areas of values.

* دكتوراه دولة في الفقه وأصوله، المعهد العالي لأصول الدين، جامعة الزيتونة، تونس، و9 إم، أستاذ التعليم العالي،

ووزير سابق للشؤون الدينية في تونس. البريد الإلكتروني : alkhadmi@yahoo.fr

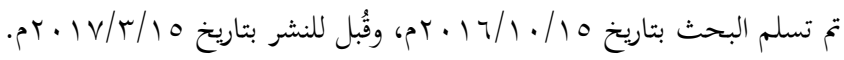




\section{مقدمة:}

يتنزل هـا البحثث في إطار مقاصد القرآن مـن جهة أُولى، وقِيم الإنسان الحضارية من جهة ثانية، ضمن علاقة جدلية مفهومية فلسفية، ومساحة عملية تطبيقية بسياقها،

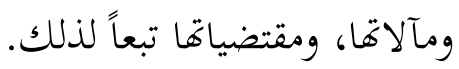

فعلى صعيد جدلية التناول المفهومي الفلسفي، يتقرر الفضاء الحضاري بُعْداً قرآنياً

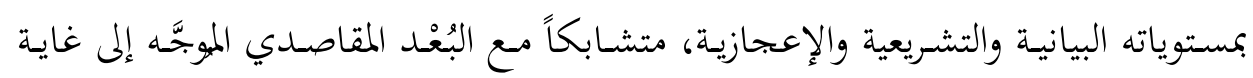

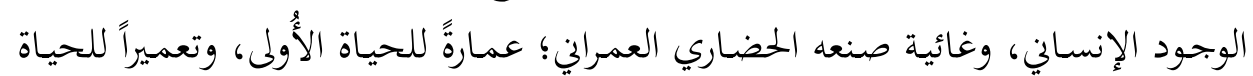
الآخرة.

وعلى صعيد جدليـة التنـاول المفهـومي للبُعْد الغـائي، يتقـرر النَّظْمُ القــرآني النصـي

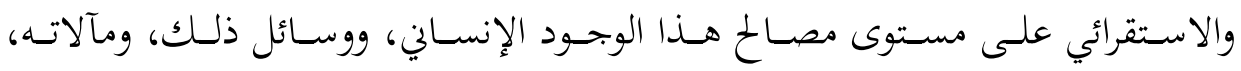
وموازناته، وقواعده، وكذا مستوى مصالح الحضارة بقيمها، وإنسانيتها، وآفاقها الرحبة في

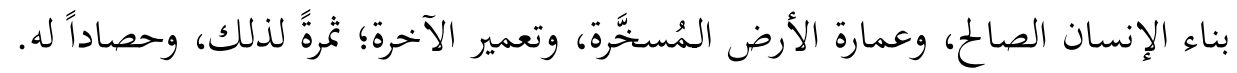
وتمثـل مقاصــ القـرآن إطـاراً معرفيـاً ومنهجيـاً وسـياقياً رحبـاً لقضـايا قِيم الإنسـان

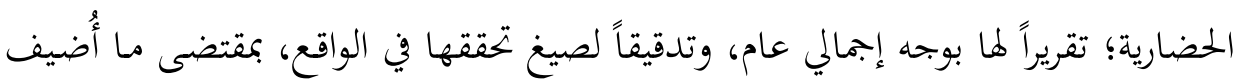

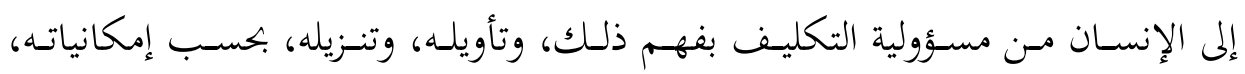
وموانعه في الحال، وآفاقه في المآل.

وهـذا الأمـ يمثل نسق الجملية القائمة المتجدددة بين مقاصد القرآن مـن جهة وقِيم الإنسـان الحضـارية مـن جهة ثانية، على مستوى الوعي، وترتيب الفكر، وتحقيق المعنى، وتحرير المصطلح، ومحل النزاع، وموطن الاختلاف ... ، وعلى مستوى التمثل في الواقع، والامتثال للمُنزل، والتحريك للمسار، والتثمير للوجود، والتعميم للمصالح والمنافع... . يهدف البحث إلى تفعيل جدلية المقاصد القرآنية والقِيم الإنسانية، وتعظيم المشترك القائم بينهما؛ إذ يشهد هذا المشترك لذلك، ويسند القول بقيام الجحلية، وتفعيلها، والبناء

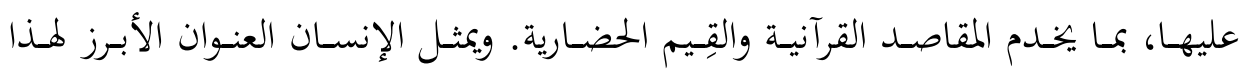


المشترك من حيث: طبيعته الإنسانية (حسن الخلق، الفطرة، مناط العقل...)، ووظيفته في تعزيز القِيم الحضارية (الاستقامة المتوازنة، الإنتاج المادي والروحي، التكامل الإنساني...)،

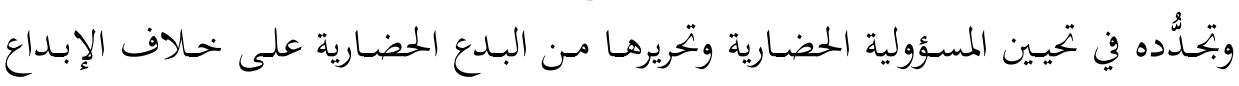
الحضاري. فالبدع هي مخالفةُ حقيقة الإنسان في وجوده الأول، وطبيعته الثابتة له؛ خحلقاً،

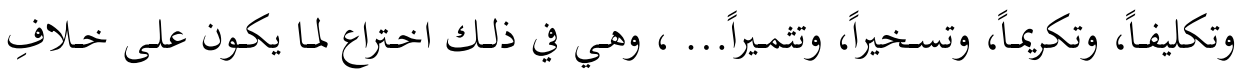

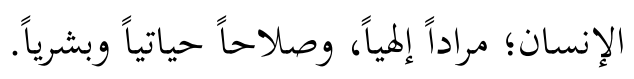

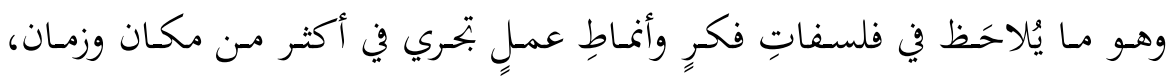

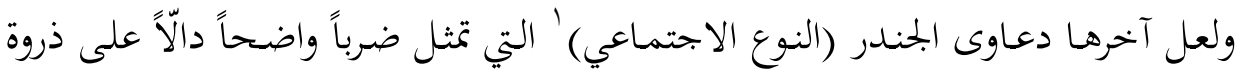

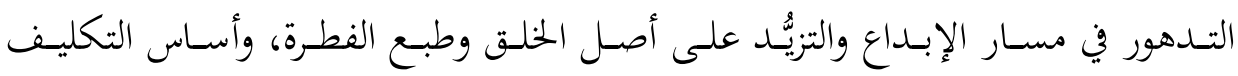
والتكـيم والتسـخير والتعمسير، بمقتضـى التكامـل بـين الجنســين في إطسار الخلـق الإنسـاني

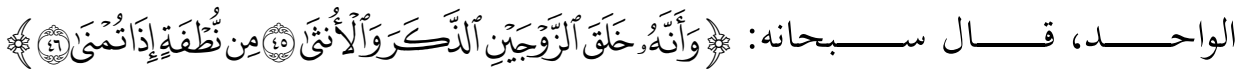
(النجم:1) (

والابتـاع مفهومهه واسع، وآفاقه رحبة، وهـو وارد في كل شيء له أصل، يأتي عليه بالإبطال، أو التشويه والتحريف؛ سواء كان هذا الأصل نصّاً شرعياً، أو خَلقاً إنسانياً، أو وأو

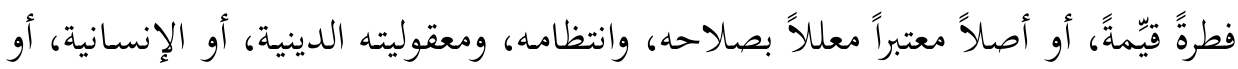
الحضارية الكونية بوجه عام.

وأمَّـا الإبـداع فهو الابتكار بمـا يخـدم القِيم الحضـارية الإنسـانية انطلاقاً مـن مقاصد

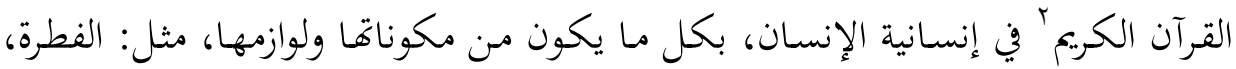

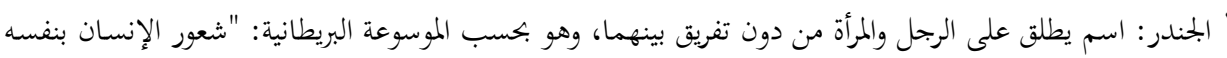

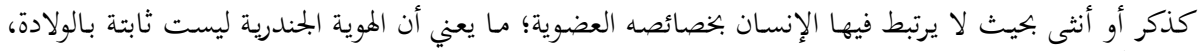

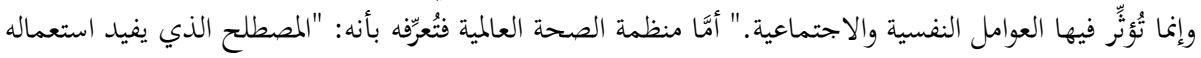

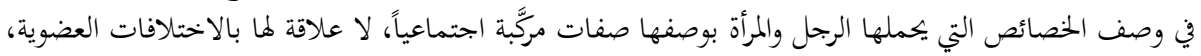

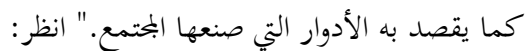

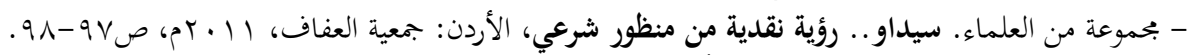

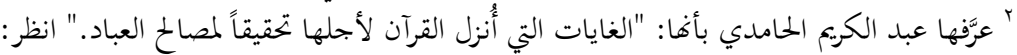

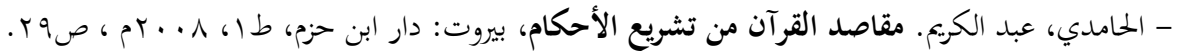


والعقل، والفرادة الجنسية، والانتظام الجمعي، والتـآلف البيئي، ومنظومـة العمارة للحيـاة والوجود.

تتمثل أهمية البحث في بتحلية مقاصد القرآن متلبسةً بقِيم الإنسان الحضارية، علماً أن هذه المقاصد بمفهومها الواسع وآفاقها البحثية والوظيفية الرحبة تمثل توجيهاً هادياً لتعزيز

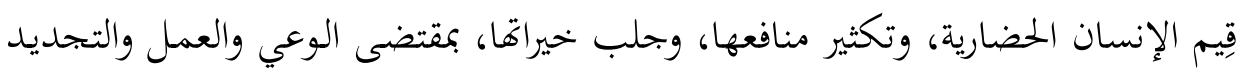
والإحياء، وبموجب تصاعد القدرات الذهنية والعملية والجهود الجماعية والمؤسسية، وأقدارِ

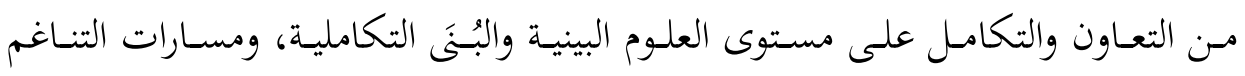
والتناسُب على صعيد التعليم، والتدريب، والمراكمة، والمراجعة.

ونحن إذ نُؤِّد أهمية الحراك البحثي للمقاصد القرآنية بآفاقها الرحبة ونظرها الفسيح،

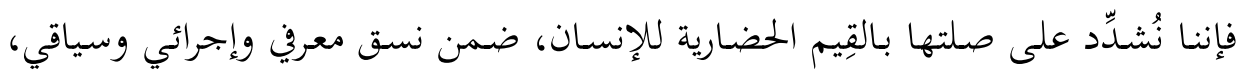
نعمل جميعاً على تقريره، والبناء عليه.

ولعل أدبيات البحث في هذا المحال كثيرة متنوعة متداخلة متكاملة.... ، فيها أقدار من التكرير مع قلة التثمير، وهي في ذلك تَعد بتجاوز مأمول، يرتقي بالبحث المقاصدي

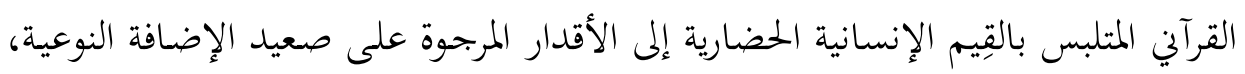

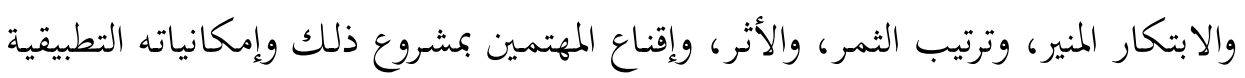

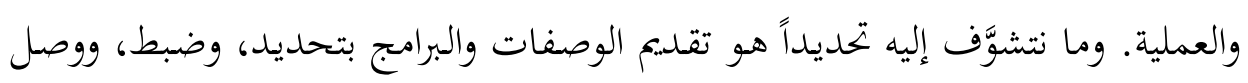
بالواقع، وربط، وتقديم الخدمة والخبرة.

\section{أولاً: مقصد إنسانية الإنسان، وإحياء قِيم الإنسان الحضارية}

إنسانية الإنسان هي حقيقة الإنسان وجوهره، ولوازم ذلك على مستوى الخصائص

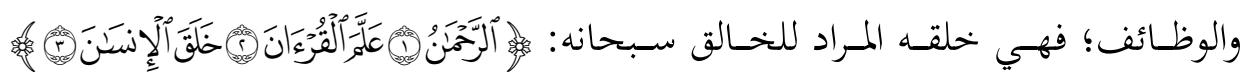
(الرحمن: إ-ب)، وهي فطرته التي خلق الله النـاس عليها وجـبلهم عليها، قـال تعـالى:

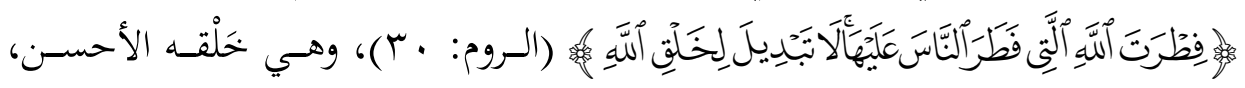

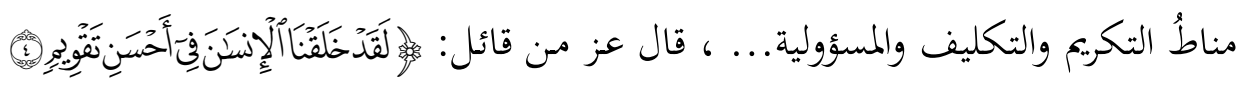




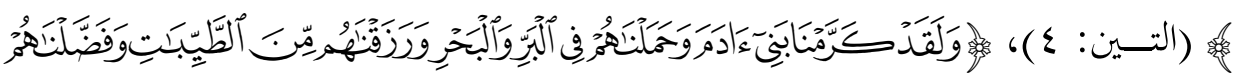

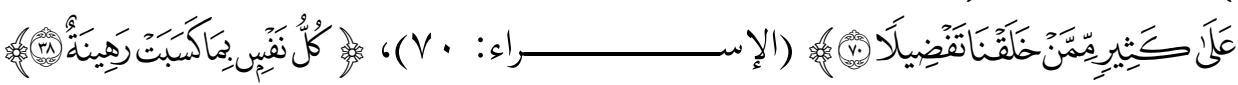
(المدثر : (ץ)

\section{1 ا إنسانية الإنسان مشتركُ مقاصدِ الشرع وقِيم الحضارة:}

لمَّا كانت إنسانية الإنسان تمثل مقاصد الشرع، فإن ما جاء من نصوص ومعقول

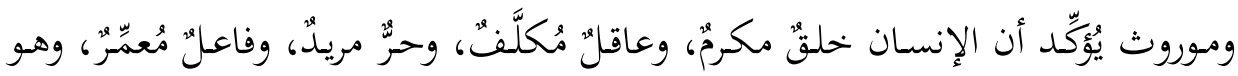

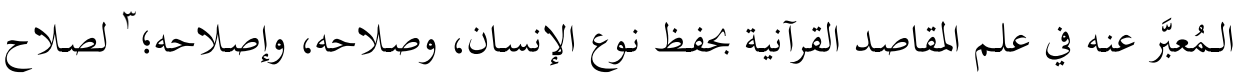

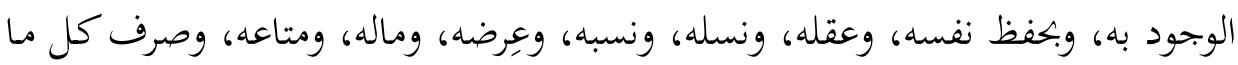
يُّلحق به الأذى في معاشه، أو العذاب في معاده.

ونصوص ذلك حافلة متضافرة متوافرة متواترة؛ ما جعلها -بعقتضى الاستقراء- ترتقي إلى مبـدأ عـام، وقاعـدة كليـة، وخصيصـة كبرى، يكـون مـن عناوينها الكبيرة "إنسـانية

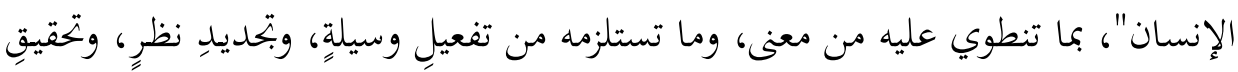
مناطٍ، وتكثيرٍ أثثرٍ وثمٍٍ.

وإنسانية الإنسان هي قيمة قِيم الحضارة؛ فقد جاء في تعريف الحضارة؛ أهنا الإنتاج

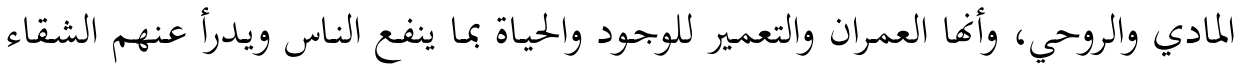
' يقول الشيخ عممد الطاهر بن عاشور : "إذا خن استقرينا موارد الشريعة الإسلامية الدالة على مقاصدها من التشريع،

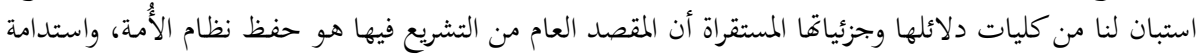

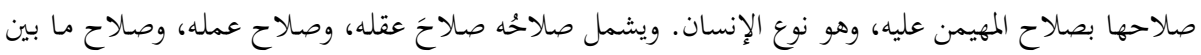

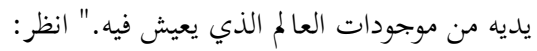

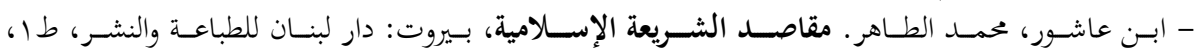

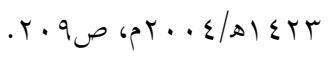

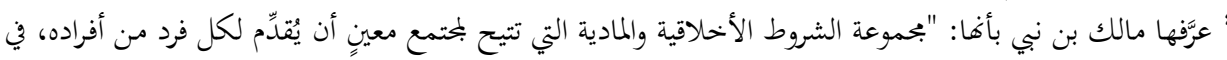

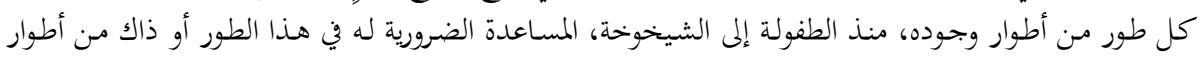

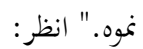
- ابن نبي، مالك. القضايا الكبرى، بيروت-دمشق: دار الفكر المعاصر، دار الفكر، طץ، ـ بـ اه/....Tم، 
والعنـاء... ومسن أظهر مـا يُعمَّر بـه الوجـود حفظظ وجـود الإنسـان، وسـلامته في نفسـه،

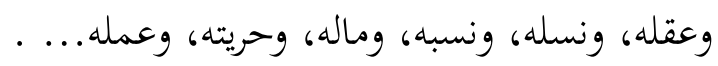

وهذا يمثل المشترك الجوهري (الذي هو الإنسان) بين مقاصد القرآن المؤسسة لوجود

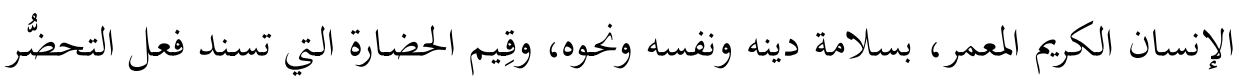

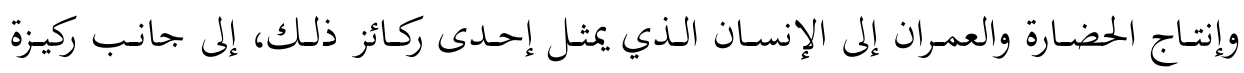

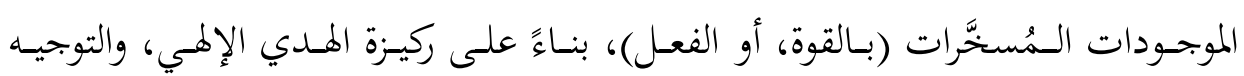

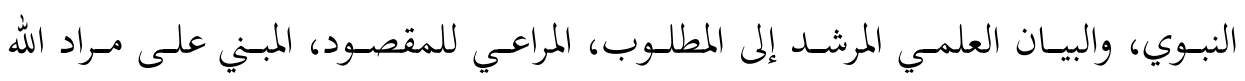
سبحانه وتعالى.

وتردُّد إنسانية الإنسان بين مقاصد القرآن وقِيم الحضارة يمثل مشتركاً عظيماً بينهما،

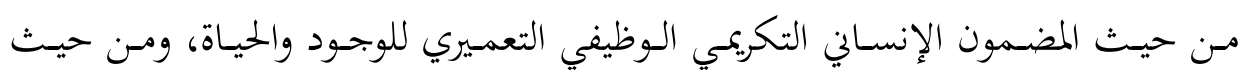

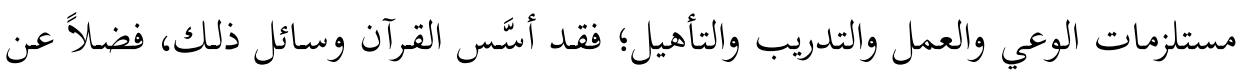

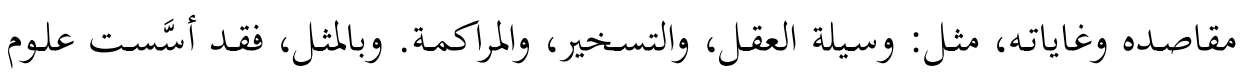

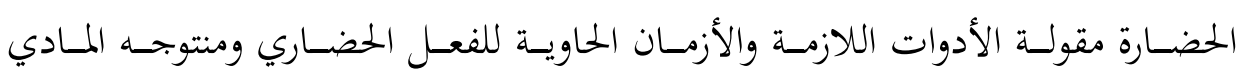
والروحي... وهذا المشترك الوسائلي على صعيد مقاصد القرآن وقِيم الحضارة يمثل قدراً

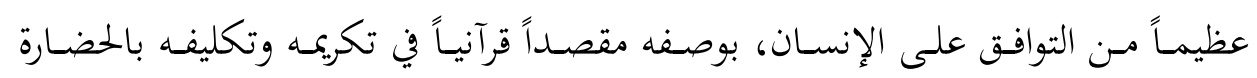
والعمارة، وبوسائل ذلك من حيث إمداده بالعقل، والإرادة، والحرية، والمسؤولية، والإطار

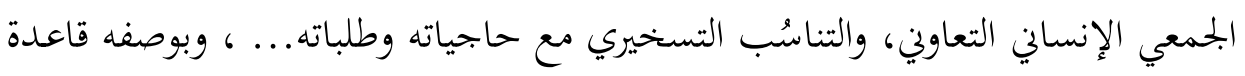

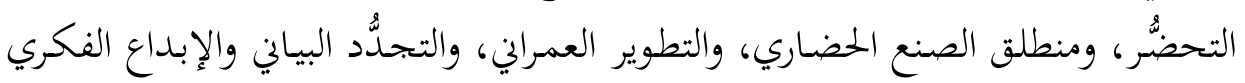
واللساني.

\section{Y . إنسانية الإنسان بين المُهدِّدات والمشتركات:}

تتهـد إنسانية الإنسـان مـن حـين إلى آخر بمقتضى التطورات الفكرية والاجتماعية

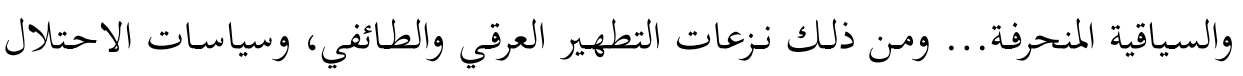

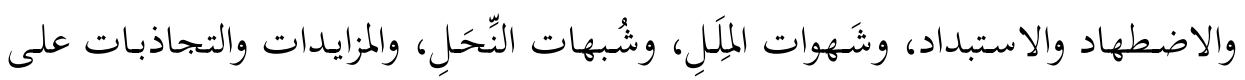

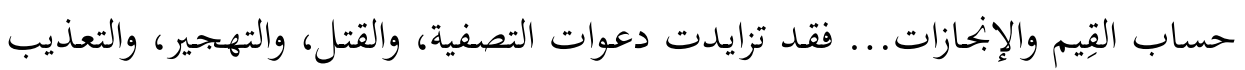




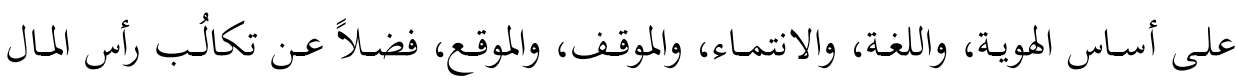

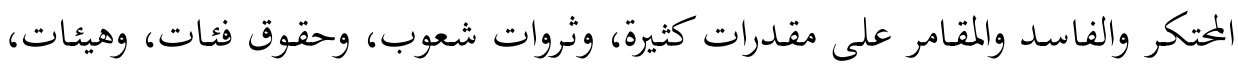

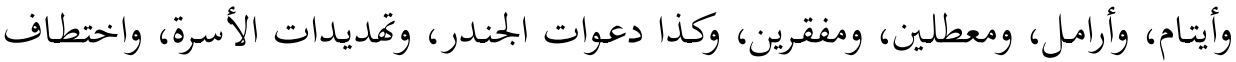

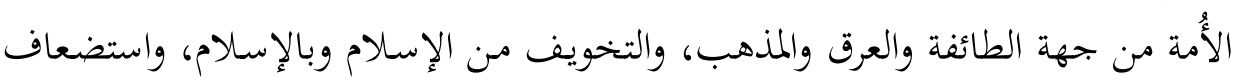

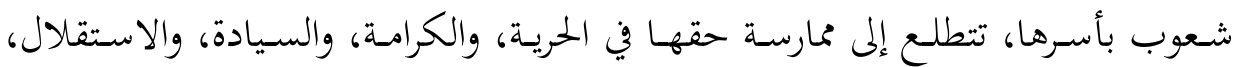

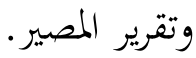

وبجمل مآل ذلك هو تعطيل التنمية الحضارية والإنحاز العمراني النافع للناس جميعاً...

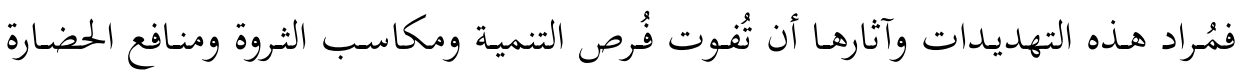

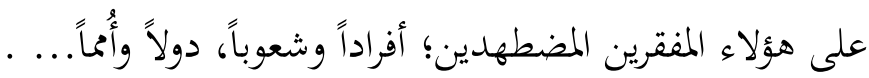

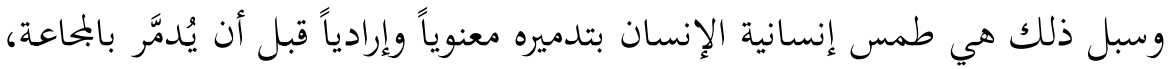

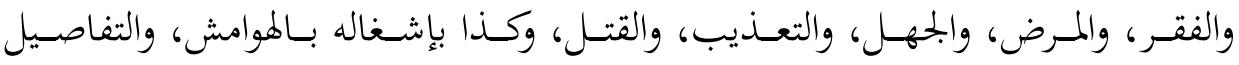

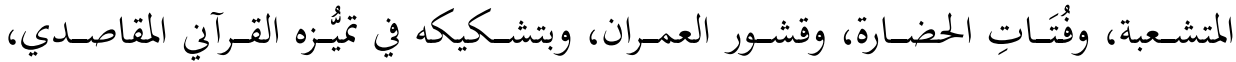

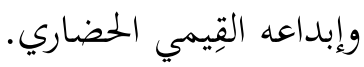

فلا عجب إذن أن يتعاظم الدور التحريفي الخطير لرسالة القرآن في بناء الحضارة

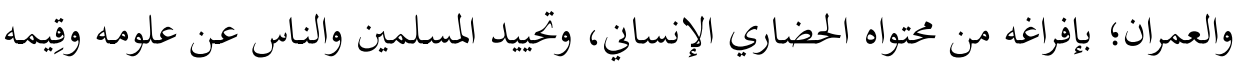

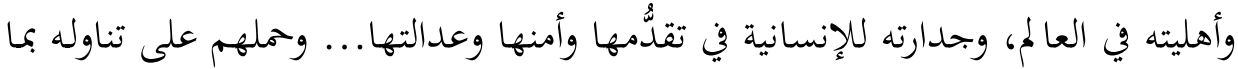
هو دون ذلك، مثل: حفظه من دون فهمه، وتدبُّر نظرياته وعلومه والتبرُّك به في زوايا

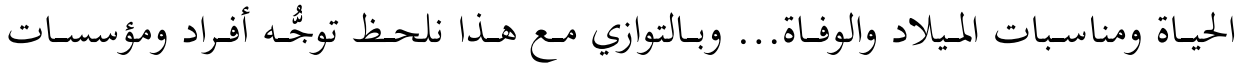
يعملون على خلخلة رسالة القرآن، وإرادة التشكيك فيه؛ سنداً، ومتناً، وحَيَاً مباركاً، وأثراً

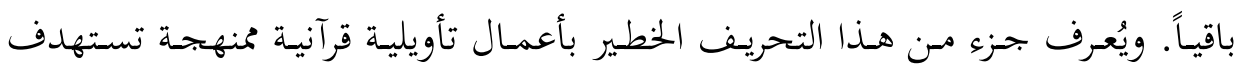

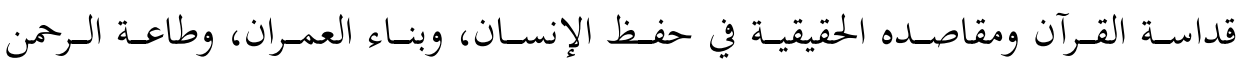
سبحانه.

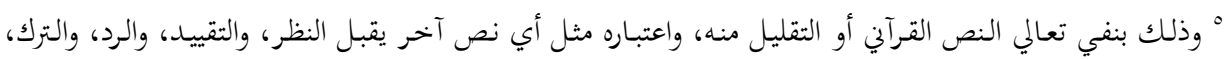

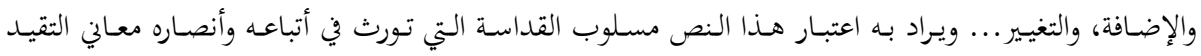




\section{ب. فشل مُهدِّدات إنسانية الإنسان بتعزيز المشتركات:}

بوسع القـائمين على مقاصـد القـرآن (نظراً، وعمـالً)، وعلى قِيم الحضـارة (فكراً،

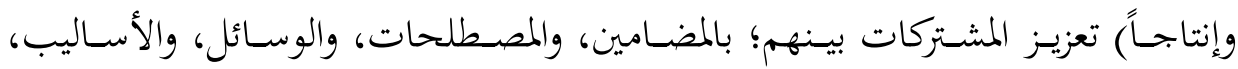

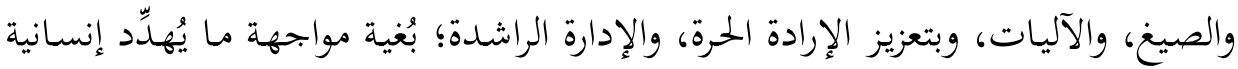

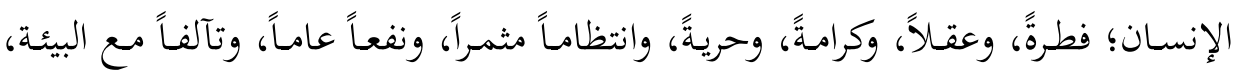
واستئناساً بالطبيعة، وسعادةً بالحياة، وفوزاً بالآخرة. ... . .

وهو الأمر الذي يستوجب أقداراً عاليةً من التفاهـات على صعيد التكامل المعرفي

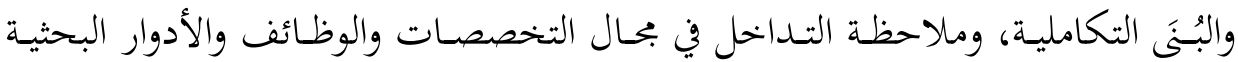

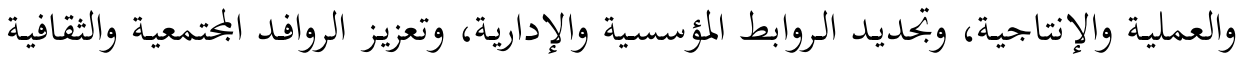

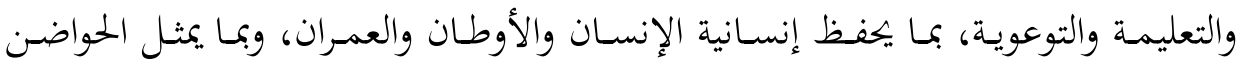

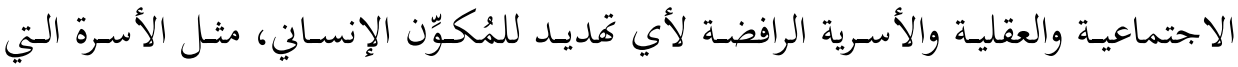

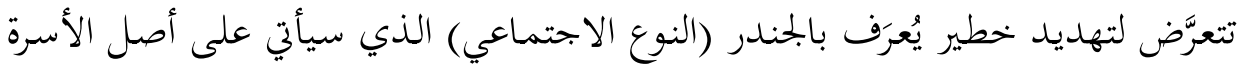

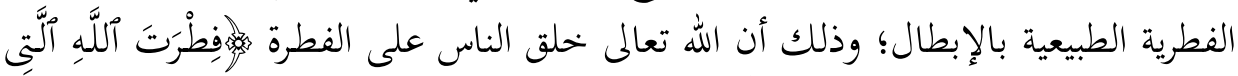

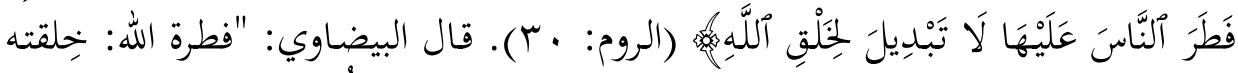

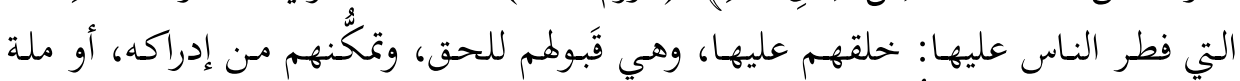

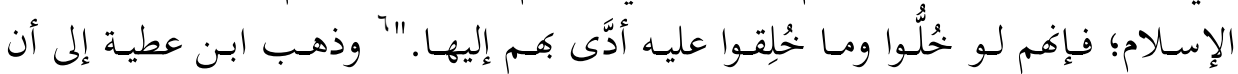

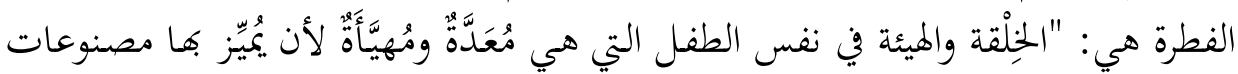

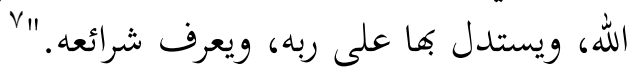

بأحكامه، والاعتزاز به، والدفاع عنه، والانتصار له، والدعوة إلى إرسائه وتفعيله، بناءً على تعالي النص وقداسته ومرجعيته. انظر: و الاعتراز

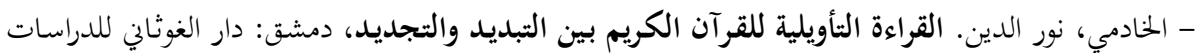

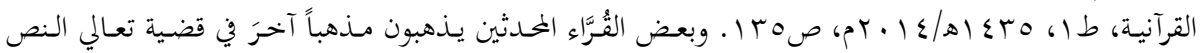

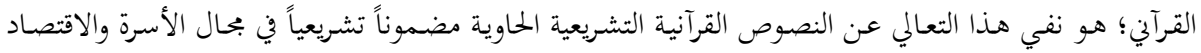

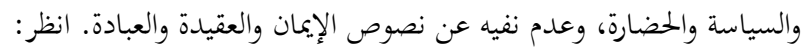

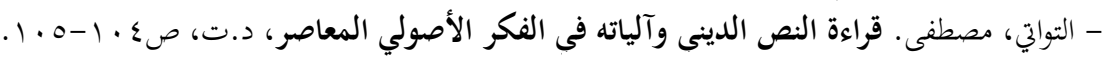

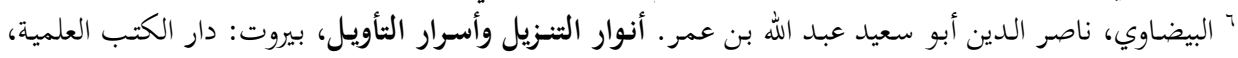

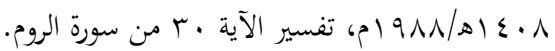

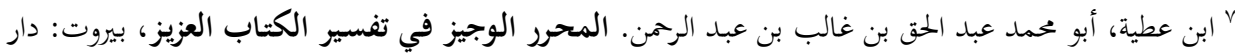

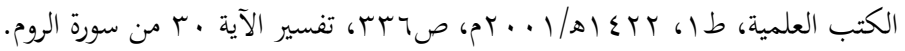


ومسن المقترحسات في هـذا الصـدد، بحـث روابطط العلـم والمـنهج والإجـراء بـين مقاصـد

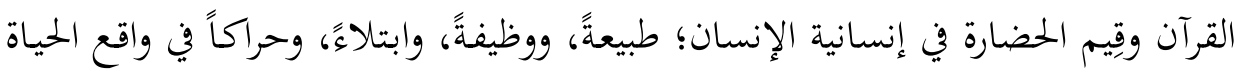
وتحديات الوجود، وصراعاً مع دعوات التهديد والتدمير.

\section{ثانياً: مقصد فرادة الإنسان الجنسية، وإحياء قِيم الإنسان الحضارية}

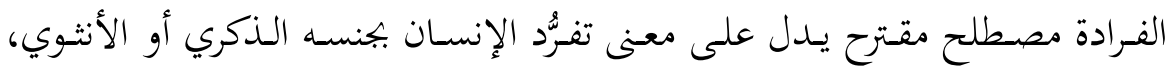

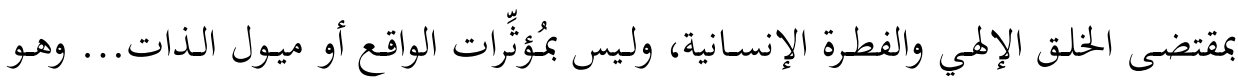

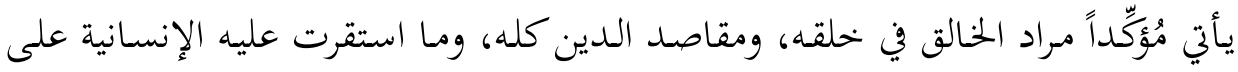

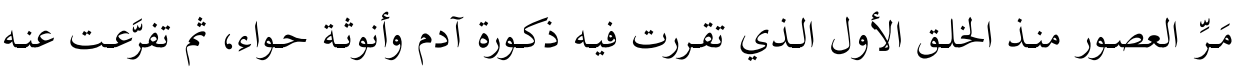

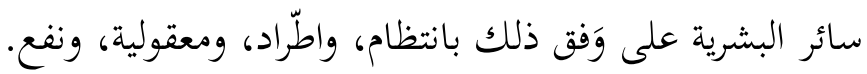
وهو يأتي ردّاً على المصطلح الغريب العجيب (الجندر= النوع الاجتماعي) الذي لم

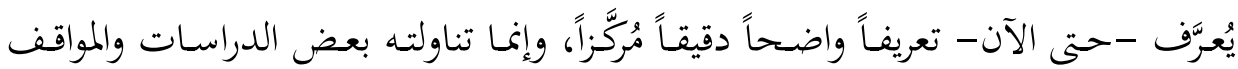

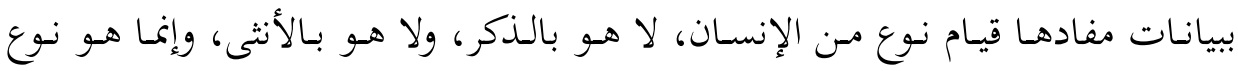

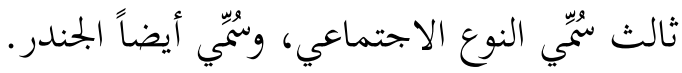

وهـذا النوع مـن الإنسـان لا يقف جنسـه عند هـا الحـد (لا ذكر، ولا أنثى)، وإغنـا

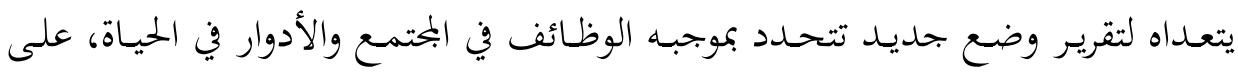

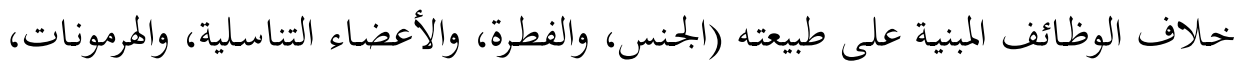

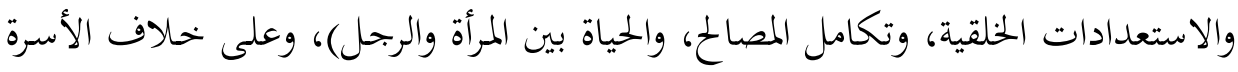

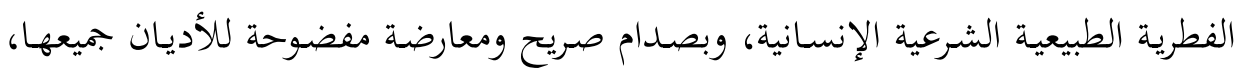

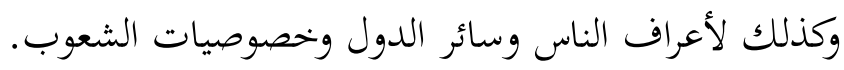

ومفـاد هـا التحريف الخطير لمفهوم الإنسان والأسرة هو الوصول بـه إلى ما يُعرَف

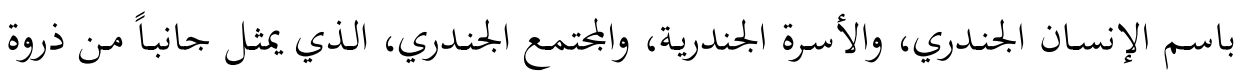

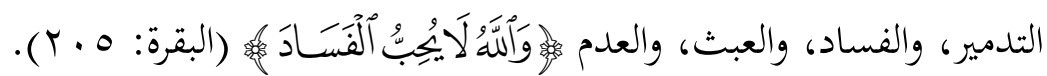




\section{1 ـ حقيقة الجندر وأسسه الهاوية: ^ \\ ترتكز دعوى الجندر على أساسين اثنين:}

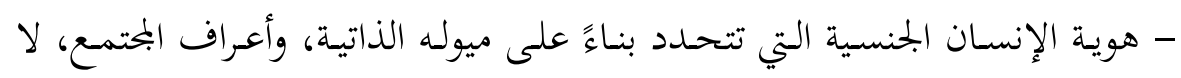

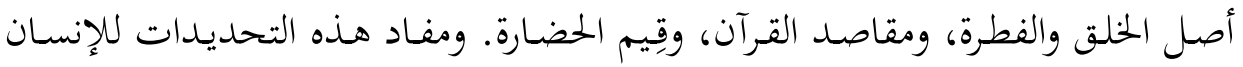

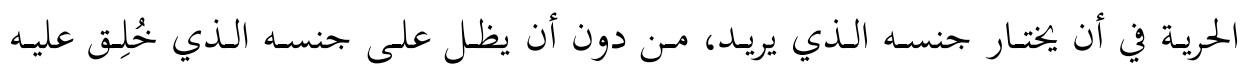

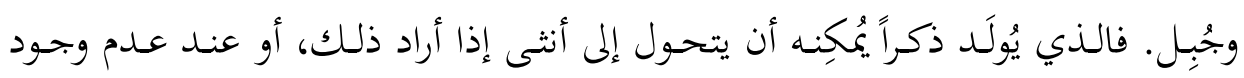

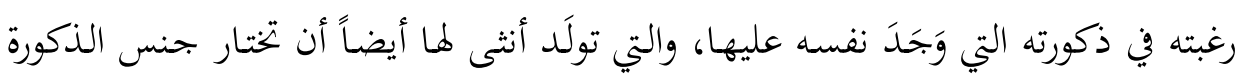

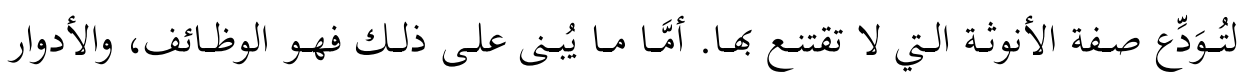

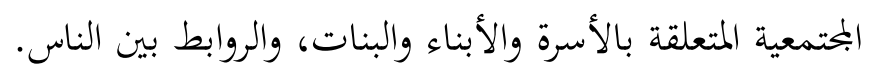

- وظائف الإنسان وأدواره التي تتحدد بناءً على هويته الجنسية الجندرية، لا هويته

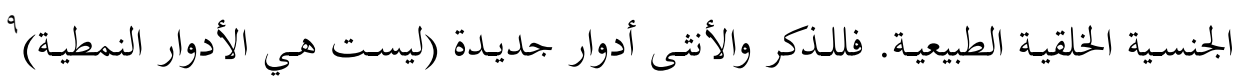

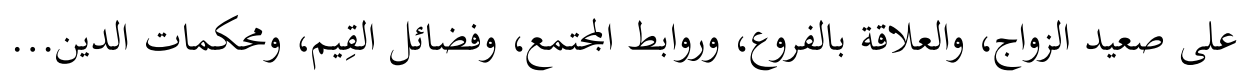
وتعد الأسرة الفطرية الشرعية في نظر مروجي فكرة الجندر أسرة نمطية، لم تعد صالحة

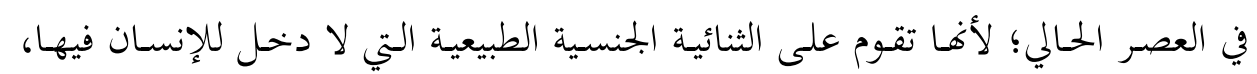

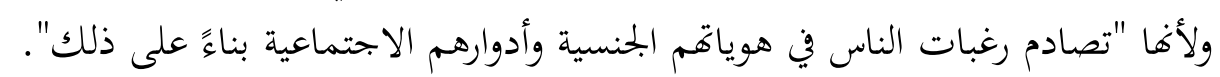
وقد لزم من ذلك إمكان قيام الأسرة الجندرية على رابطة بين اثنين يختلفان في الجنس

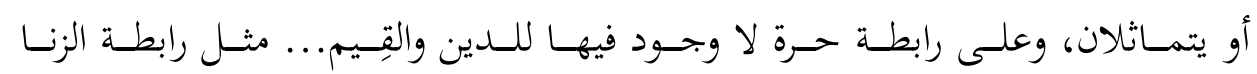

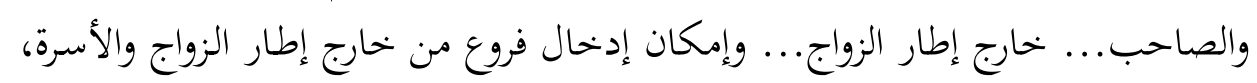

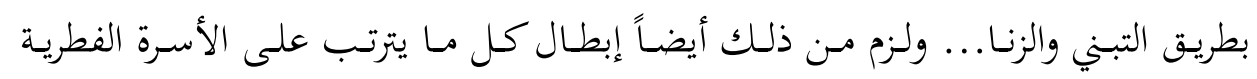

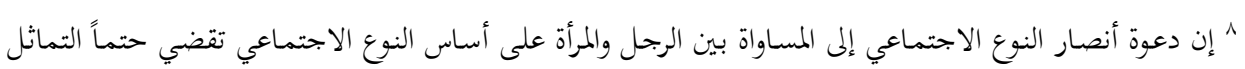

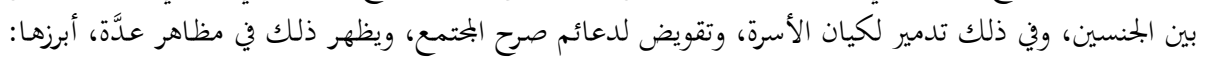

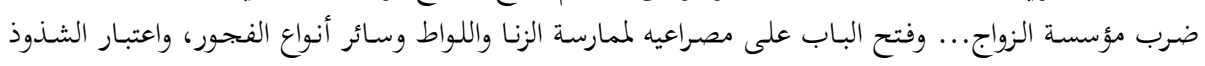

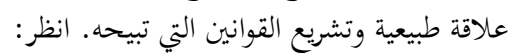

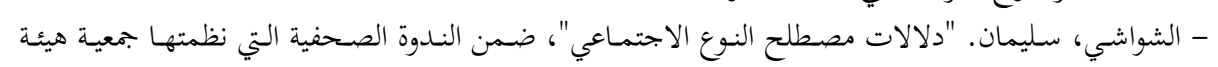

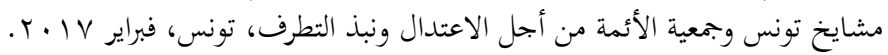

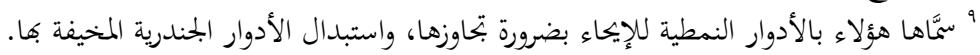


الشرعية من مقاصد المودة والرحمة والسكينة، بمقتضى الميل المتبادل بين الزوجين، والعشرة

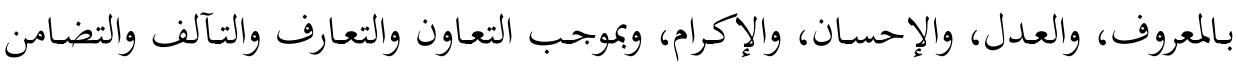

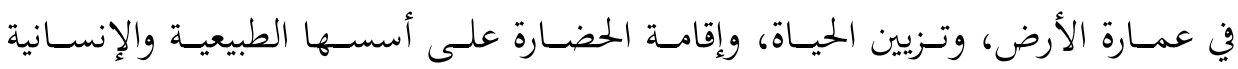

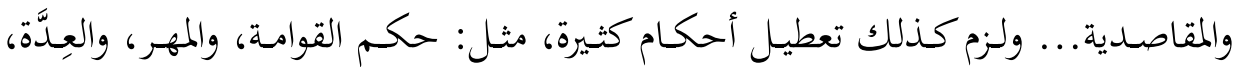
والمواريث، وغير ذلك.

\section{Y. أوجه مقاصدية القرآن في الفرادة الجنسية:}

أ. مقاصد مراد الله تعالى في الخلق الإنساني: فقد أراد الله تعالى خلق الإنسان خلقاً

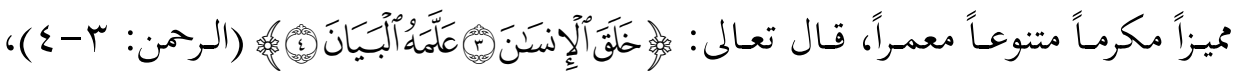
وقال سبحانه: ب. مقصـد مـراد الله تعـالى في خلق الإنسـان ذكراً وأنثى : فقـد أراد سبحانه تنويع

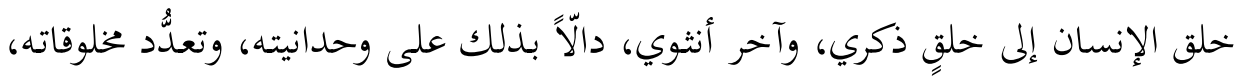

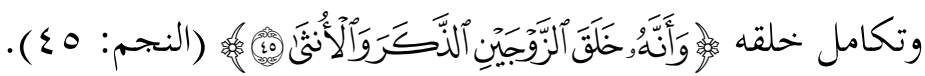

ت. مقصد التكامل والتعمير والمسؤولية: تَرد الثنائية الجنسية في إطار تكامل الوجود الإنساني ولوازم ذلك من حيث جمال الوجود، وتبادل الميول، وثراء العمارة، ومن حيث

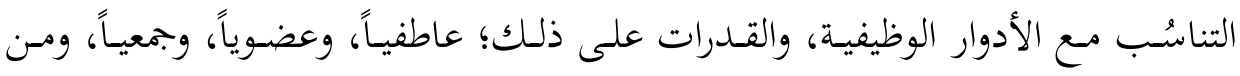
حيث تأمين المسار الإنساني، ودرء ما قد يؤذن بخرابه وفساده وفوات مصالحيه، والحه. ث. مقصد الابتلاء والجزاء: هو المقصد الذي يُعنى بابتلاء الوجود الإنساني واختباره

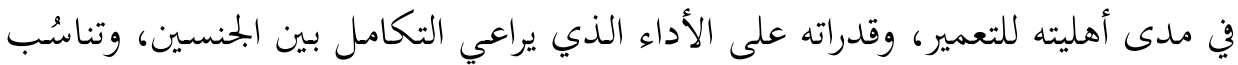
أدواره، واستمرار أدائه، وتعظيم ثماره.

ولعل الطرح الفكري الجحلي لمقولة الجندر يمثل ضرباً ابتلائياً عظيماً في تقرير ما يمثل

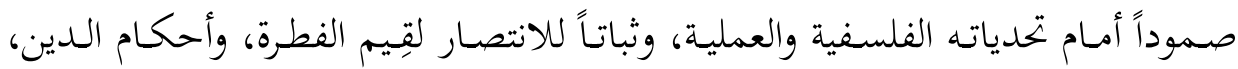

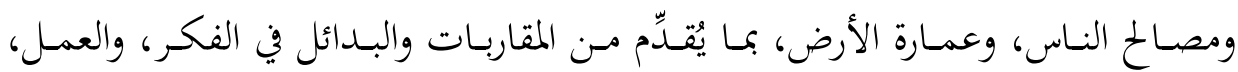
والمختمع، والدولة، والقانون، والدستور من أجل ذلك. 
ثالثاً: مقصد الانتظام البشري الجمعي، وإحياء قِيم الإنسان الحضارية

يمثل الانتظام الجمعي مقصداً قرآنياً معتبراً، وقيمةً حضاريةً كبرى؛ فهو مقصد قرآي

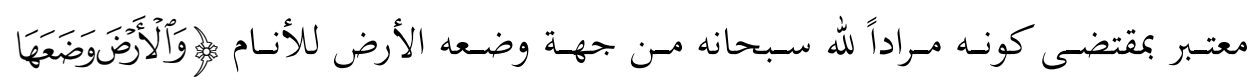

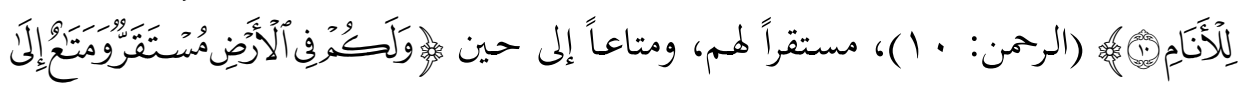

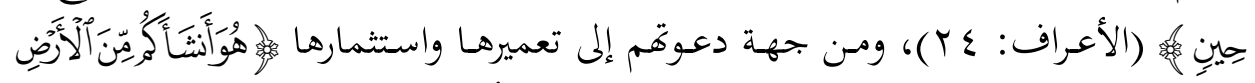

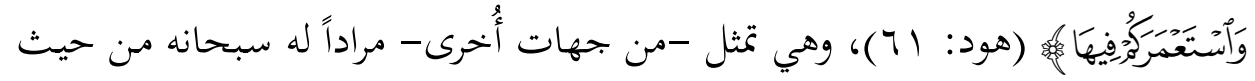

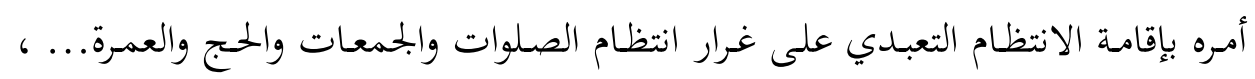

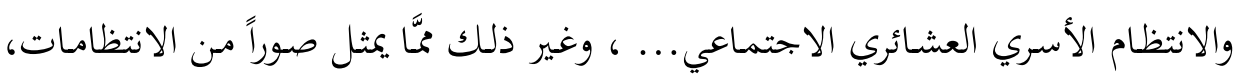
مثل: الانتظام المسجدي، والوطني، والدولي، والأُميم، والإنسائي.

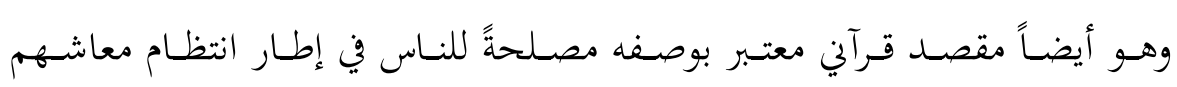
بمستويات ذلك وسياقاته، مثل: مستوى الانتظام التجاري والزراعي والعمراني بوجه عام، ومستوى الانتظام التعليمي والثقافي والمحتمعي، بما يسدد تلك المصلحة بمراتبها الضرورية

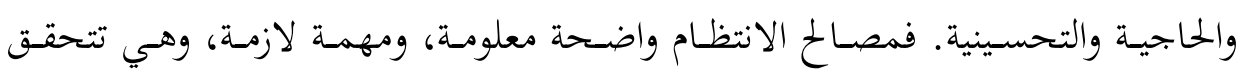

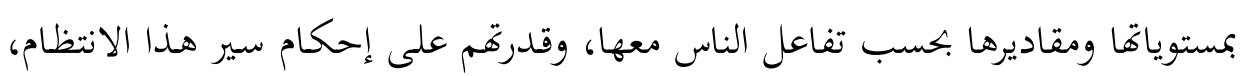
وتحقيق ثماره، وتقدير عواقبه.

وهو أيضاً مقصد قرآني معتبر بوصفه إطاراً من الوسائل التي تفضي إلى مقاصدها؛ إذ يبدو أشبه بما يؤدي إلى غاياته وتحقيق مصالحه بالنسبة إلى المنتظمسين، ومثاله انتظام

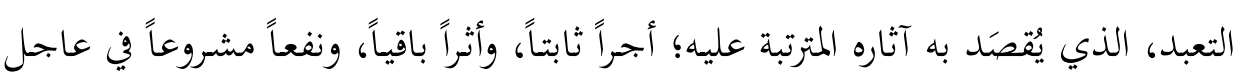

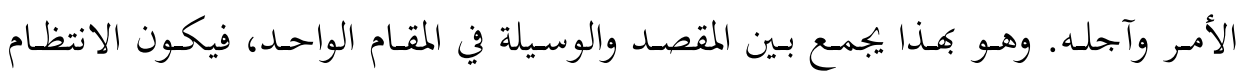
مقصداً في حدِّ ذاته، مثل دخوله في مراد الله وأمره، فيكون بهذا الاعتبار مقصوداً وغايةً

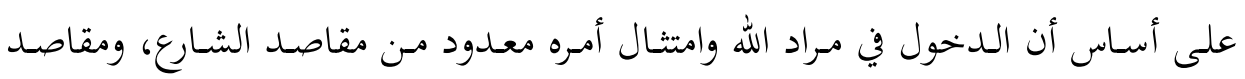

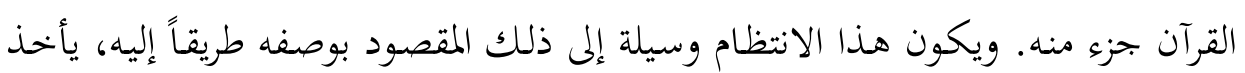
حكمه حكم ذلك المقصود. 


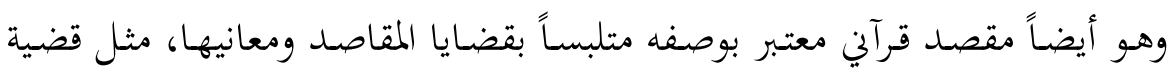

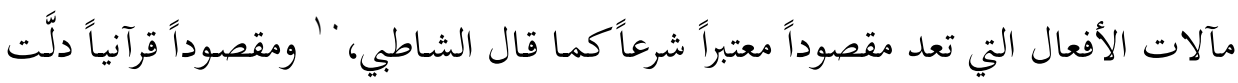

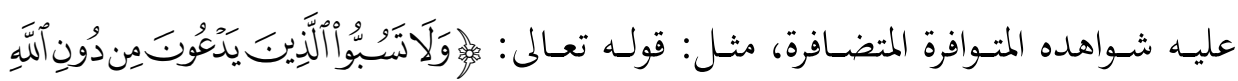

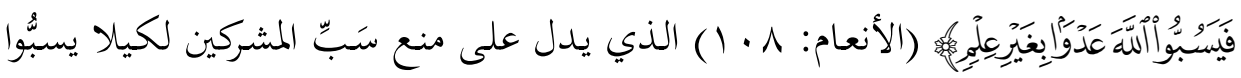

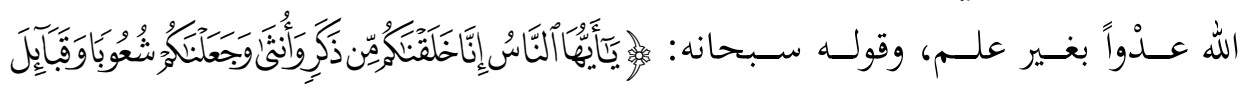

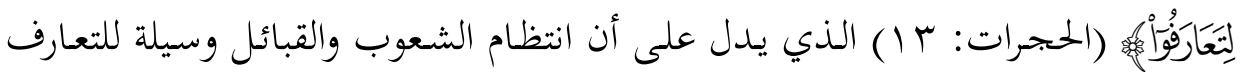

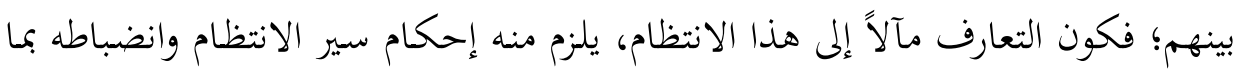

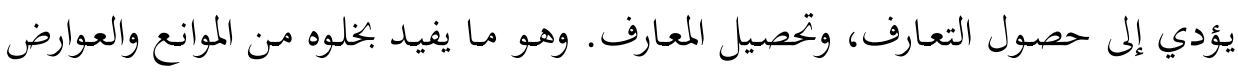

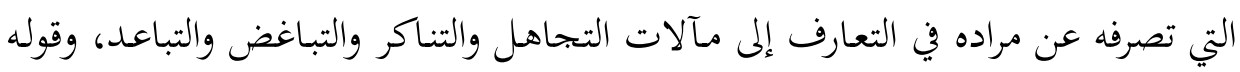

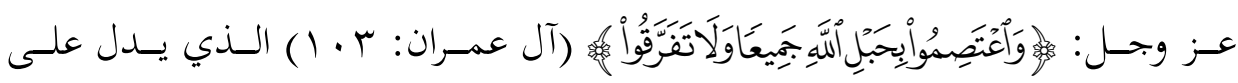

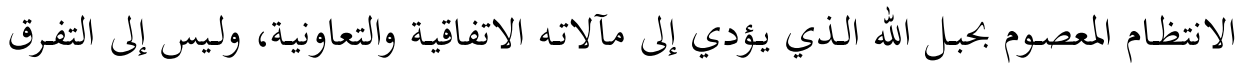

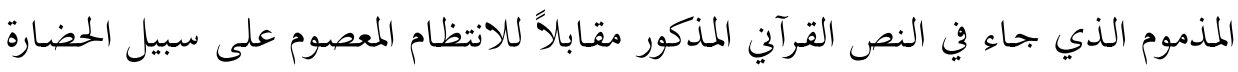

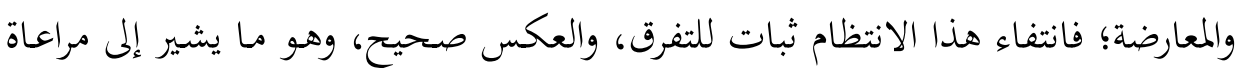
مآلات الانتظام المعصوم بنفي التفرق والتباعد، وتقرير الاجتماع والتقارب.

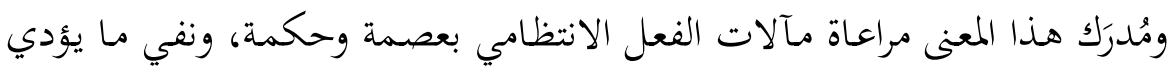

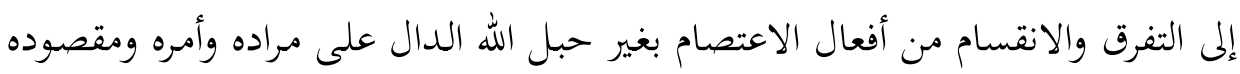
وتوجيهه بوجه عام.

ومن القضايا أيضاً قضية الجمع بين مبنى الانتظام ومعناه؛ فالمبنى هو أحواله الظاهرة

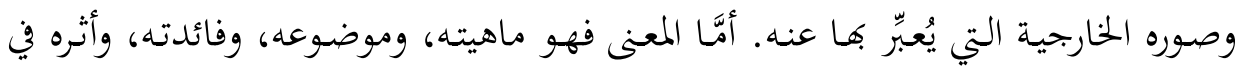
البناء الإنساني والعمراني، وتحقيق مراد الله ومصلحة المخلوق.

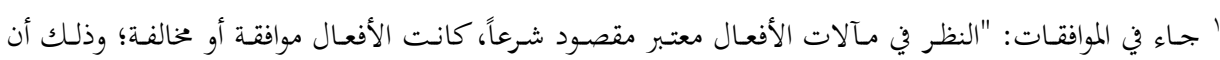

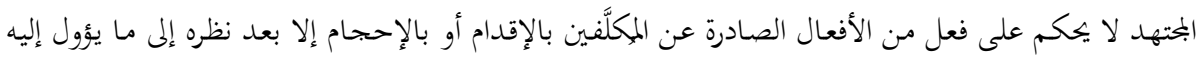

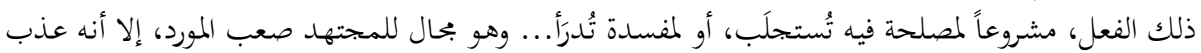




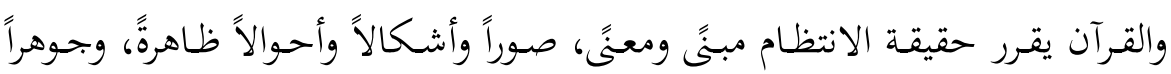

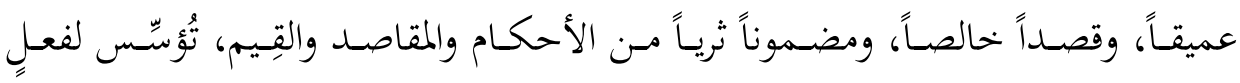

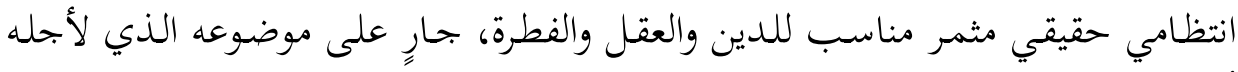

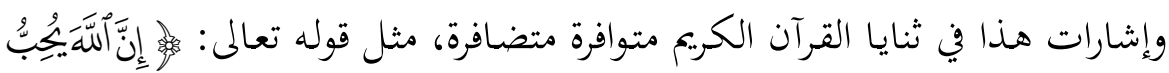

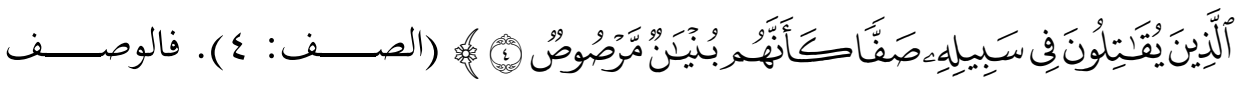

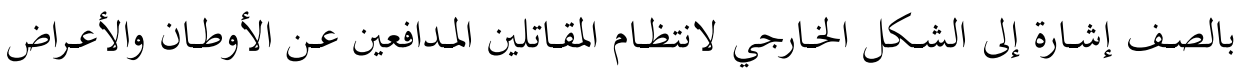

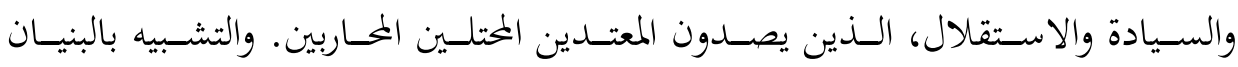

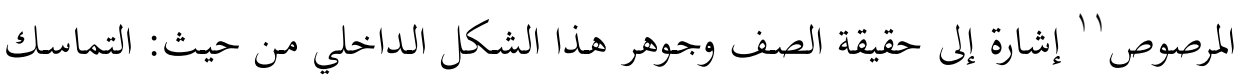

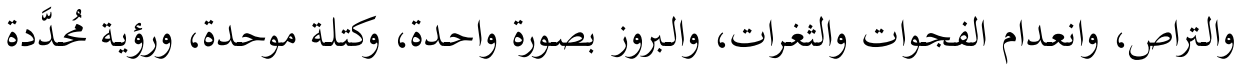
كُقُقَّة.

قال الشيخ محمد الطاهر بن عاشور: "فالصف هنا: كناية عن الانتظام والمقاتلة عن

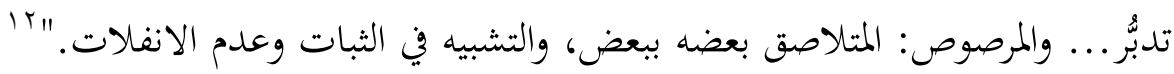
فهـذا الشـكل الانتظـامي الـوارد في نص قوله المـذكور إنما هـو انتظـام في الظـاهر

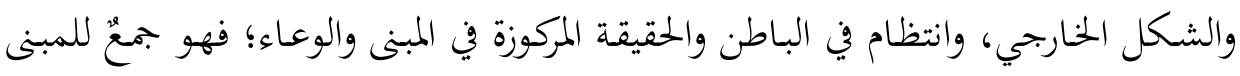

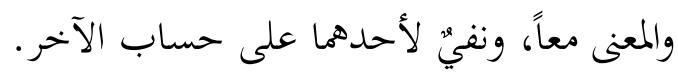
وهو ما يُعبِّ عن مقصد القرآن في الانتظام في هذا الشاهد، وفي سائر أمثاله منّّا ورد

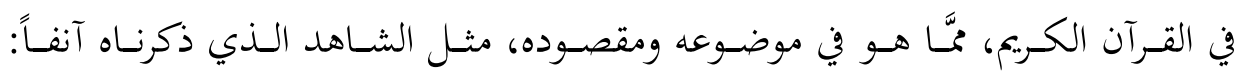

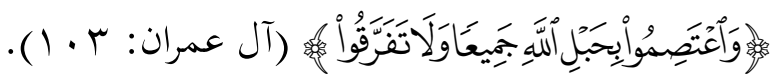

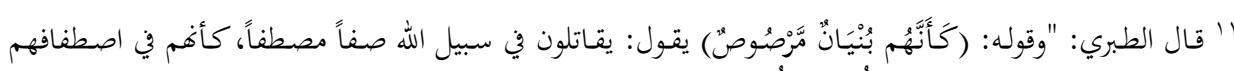

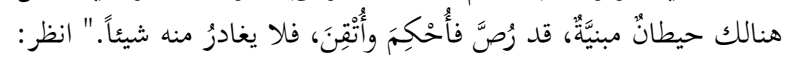

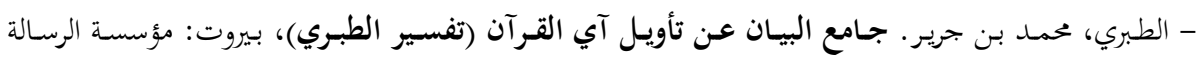

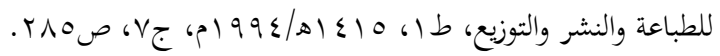

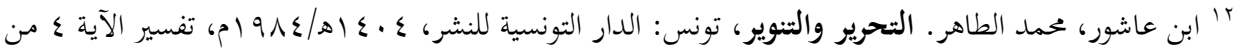
سورة الصف. 
ومن القضايا المقاصدية التي تناولها القرآن الكريم في موضوع الانتظام الجمعي، قضية

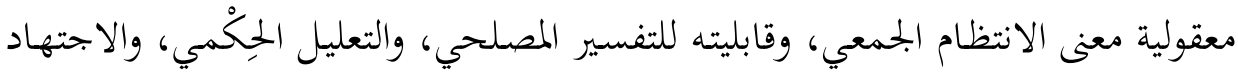

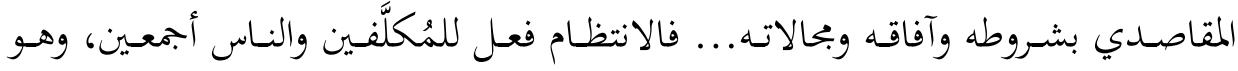

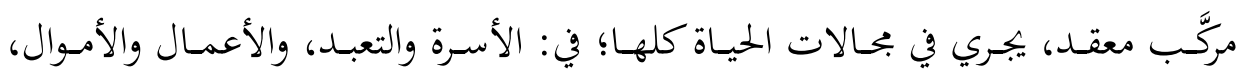
والسياسة والإدارة، والفنون والرياضة، والحرب والسلم، والفرح والترح... .

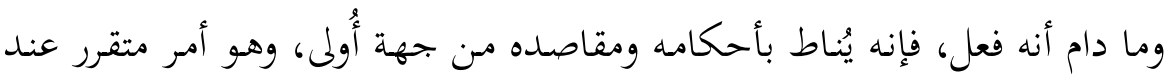
العلماء من الفقهاء والأصوليين، الذين تناولوا موضوع الفقه الإسلامي والتكليف الشرعي

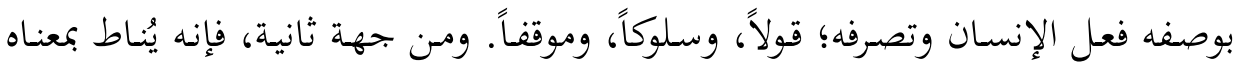
وبما وراءه. وهذا الانتظام نوعان من حيث المعنى: - انتظام معقول المعنى، وِكمه ظاهرة، وتفسيره بَيِّن، ويقبل التعليل، والقياس عليه،

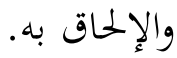

- انتظام غير معقول المعنى، وهو المعروف بالتعبدي الذي لا تبدو حِكمه ظاهرة،

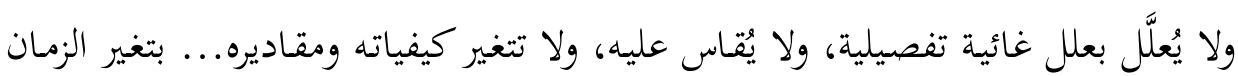
والمكان والأحوال والأعيان.

وهذا ملحوظ بكثرة وافرة في بحال التعبدات والمقدرات، على غرار الصلاة، والحج؛

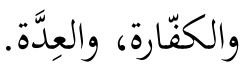

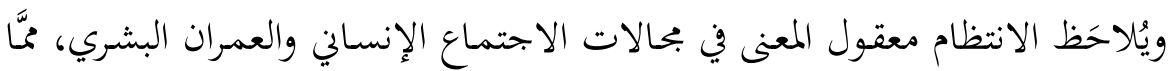

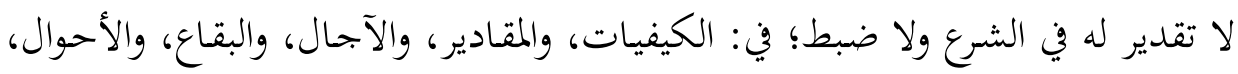

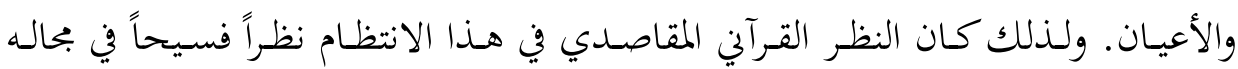

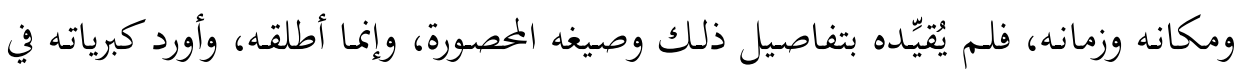

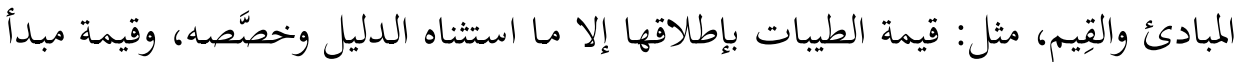
العمارة والزراعة والتجارة والصناعة. 
ويمثل الانتظام الجمعي قيمة حضارية كبرى بوصفه نسقاً في التصوُّر والتعرُّف، وإطاراً

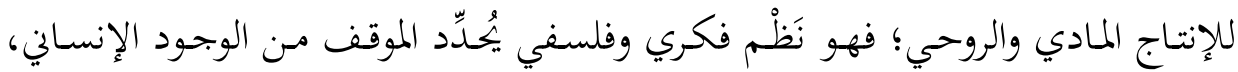

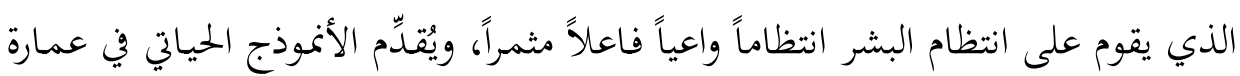

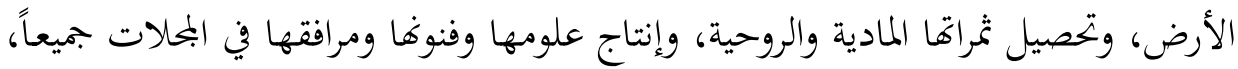

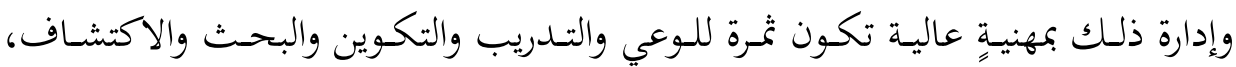

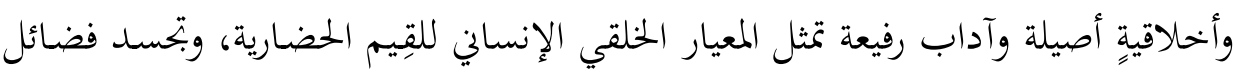
الرفق والتراحم بين البشر جميعاً.

ولأن هذا الانتظام الجمعي يمثل قيمة حضارية إنسانية عالية؛ فإنه لا ينفصل عن قِيم

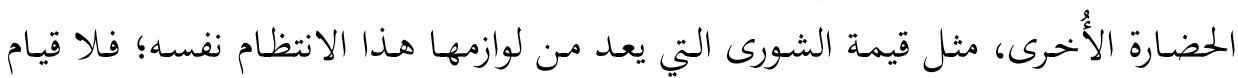

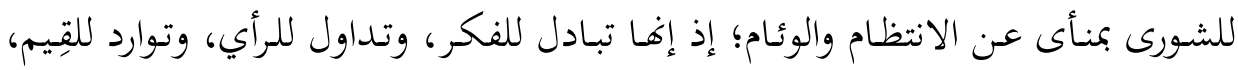

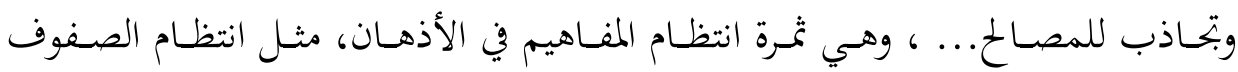

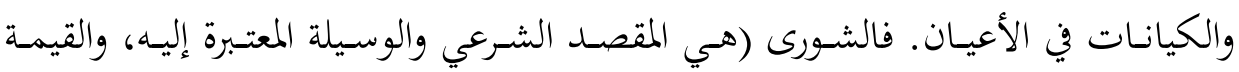
الحضارية والفضيلة الإنسانية) دلالةُ انتظام الجمع البشري بمجاله وسياقه وأحواله، مثل:

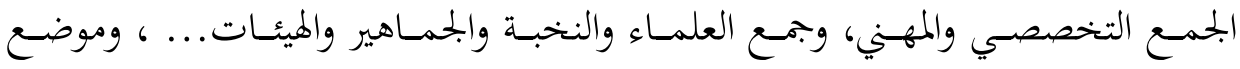

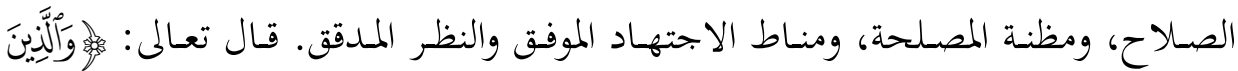

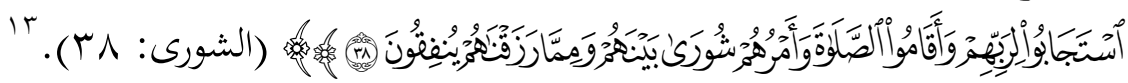
فخطابه تعالى بصيغة الجمع (أي بصيغة فعل الجماعة) يشير إلى الفعل الواعي الذي يمثل نسق الانتظام في الأفهام والأفعال، وما يترتب عليه من أنساق الإنتاج ونظم الإنجاز.

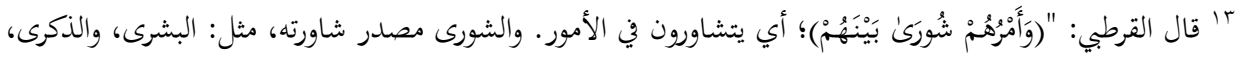

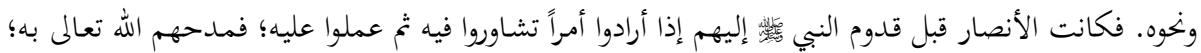

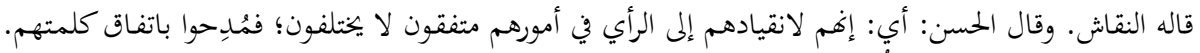

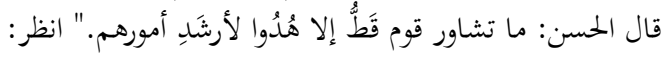

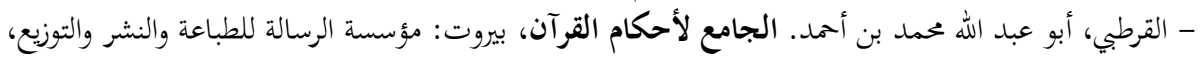

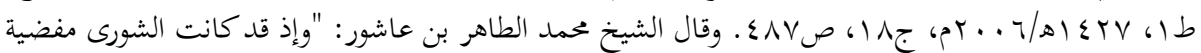

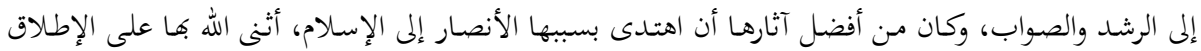

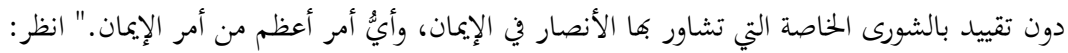

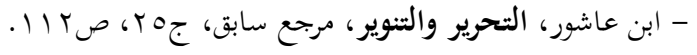




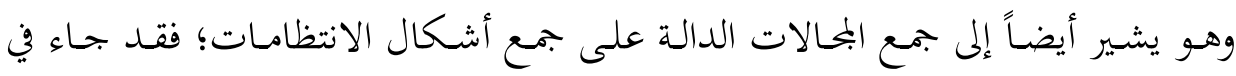

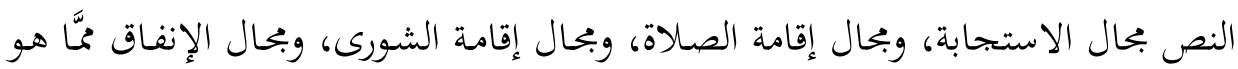

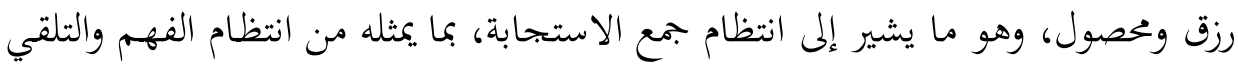

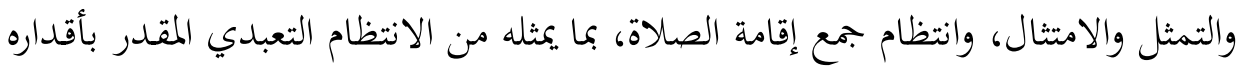

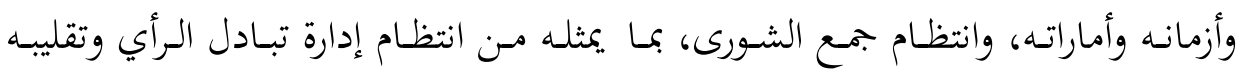

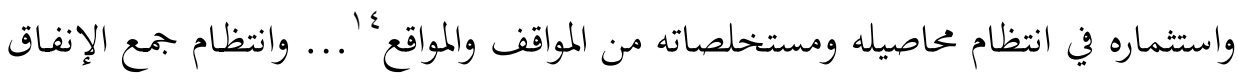

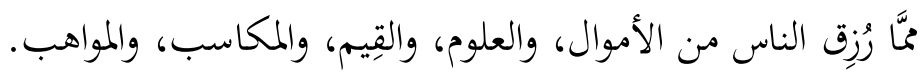

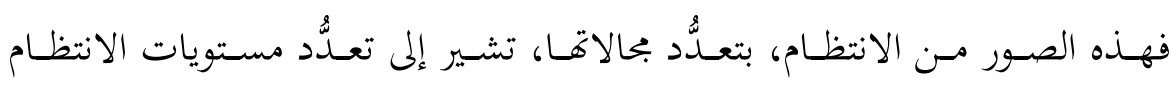

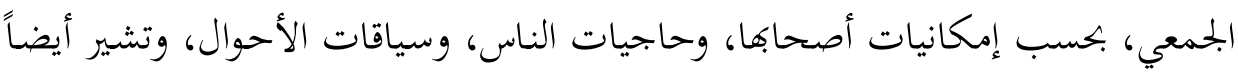

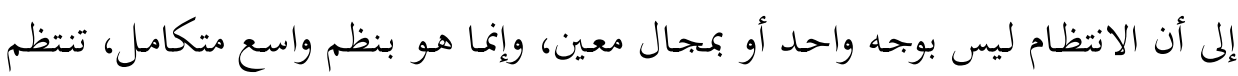

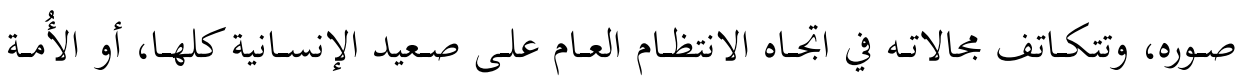
الإسلامية نفسها، أو الدولة والإقليم ونحوه.

وفي كل الجحالات والمسـارات، فـلا يليق، بـل لا يجهوز في هـدي القـرآن ومقاصـده، إحداث الانفصام النكد بين البمالات القرآنية التي تقرر فيها لزوم الانتظام؛ سواء ما ذكر

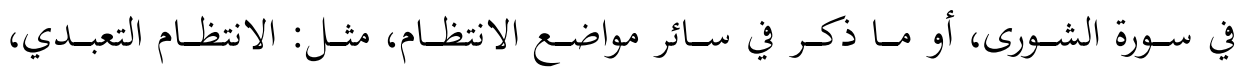

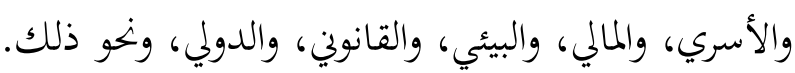

وقد آلت أحوال كثير من المسلمين إلى تضييع انتظامات جمعية عددَّة، مثل: الانتظام

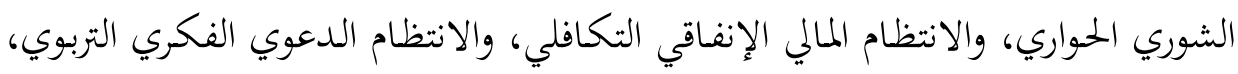

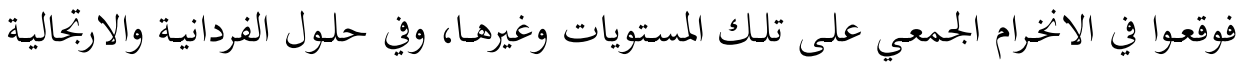

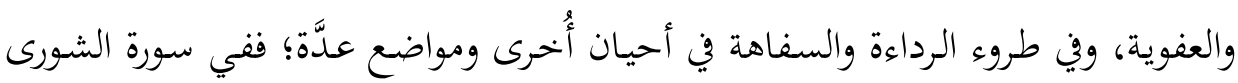

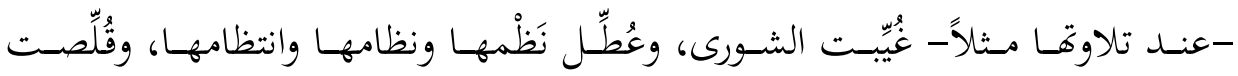

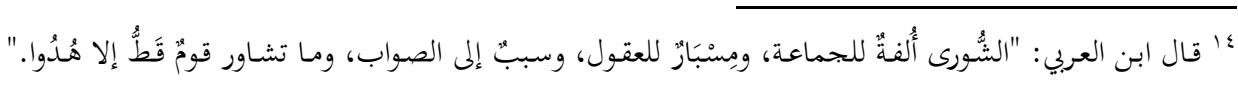


انتظامات الصلاة؛ إذ قَلَّ عدد المصلين مقارنةً بعدد المسلمين، وضعف الأثر بالرغم من كثرة الركوع والسجود والذكر والشكر. وقد انحر الإنفاق من الأرزاق في عطايا مالٍ وأعيانٍ، مع ضعف الأثر وقِلَّة الثمر، دورك

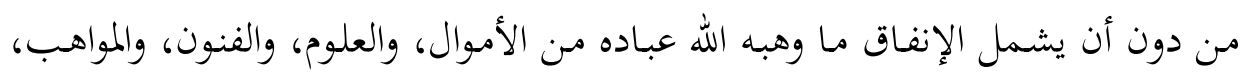
والماسب.

وهـذه الضـروب مـن الانخرام والانفصـام دليل على فوات الانتظام الجمعي في بجاله وزمانه وأعيانه؛ كلياً، أو جزئياً.

\section{- الانتظام الجمعي وصلٌ بين مقاصد القرآن وقِيم الحضارة:}

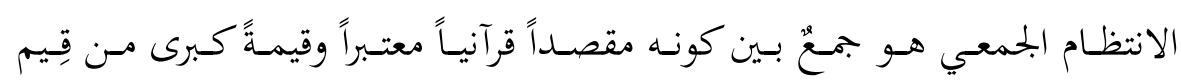

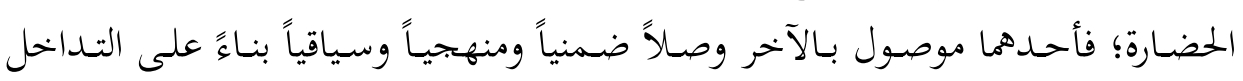

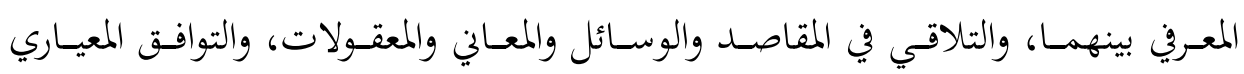
الخلقي، وميزان الفضائل وسُّلَّم الأولويات والمآلات والموازنات.

وهـذا يجعـل تحقيـق ذلك في غايـة الأهميـة النظريـة البحثيـة، والعمليـة الوظيفيـة، وفي منتهى غرس الأمل واستعادة البناء الحضاري والعمراين انطلاقاً من مقاصد القرآن المقدرة لذلك البناء، بوصفها الإطار الغائي القرآني العالي بكبريات معانيه في المصالح والوسائل والمآلات، وكبريات قِيمه في الحضارة والإنسان والوجود، مثل: قيمة الانتظام بوعي وفعل

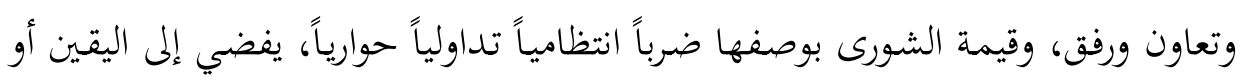
مـا في حكمـه، ويـورث الطمأنينـة والتنـاغم، ولا يؤدي إلى الريبـة والتنـازع، وقيمـة التنميـة بتزكية، والكرامة بتكليف، والحرية بمسؤولية.

والتـاخل ملحوظ -على نهوِ لافـت - بين مقاصـد القـرآن وقِيم الحضـارة في قيمـة

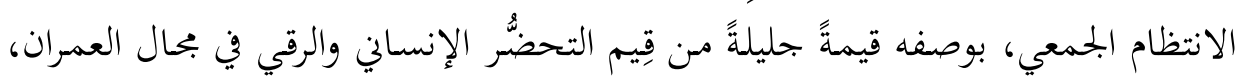

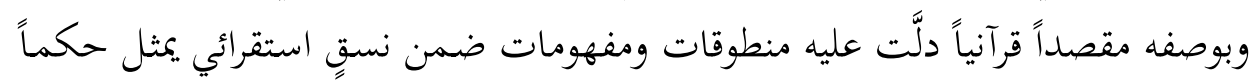


كليـاً مـن أحكـام القـرآن، واجبـة الإيمـان، ولازمـة الاعتبـار، وجــيرة بالاستثمار، والبنـاء عليها.

وما ذكرناه -بشيء من التفصيل فيما سبق - يُؤيّد هذا التداخل والتوافق بين كلِّ من

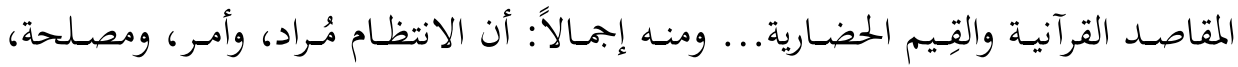

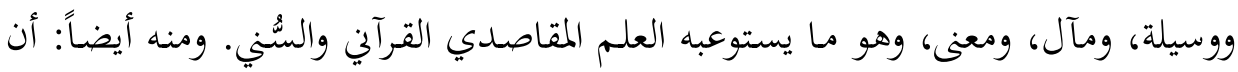
الانتظام وعي، وفعل، وإنتاج مادي وروحي، ورُقي، وتحسين، وبتميل، وتطهير، وهو ما وماني

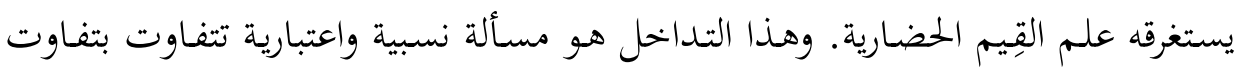

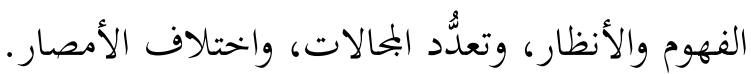

\section{رابعاً: مقصد التآلف البيئي، وإحياء قِيم الإنسان الحضارية}

يعد التآلف البيئي مقصداً قرآنياً محتفى به في ثنايا منطوق القرآن ومغهومه، وقيمةً

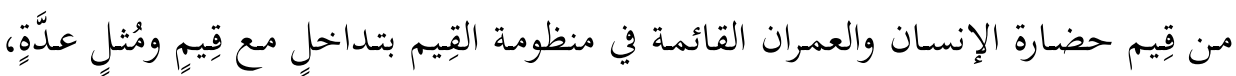

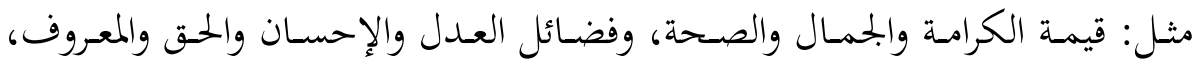

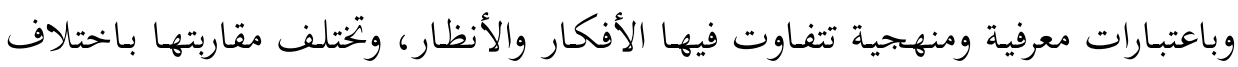
زوايا ذلك وسياقاته.

ويُعَّف التآلف البيئي بأنه التفاعل بمقتضى حقيقة الأُلفة ومستلزماتها بين الإنسان

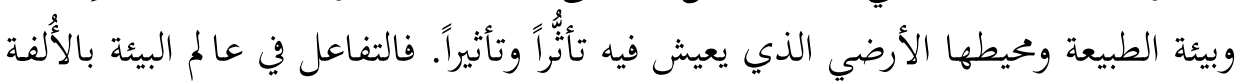

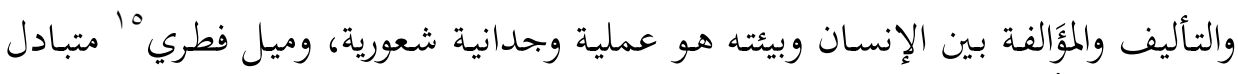

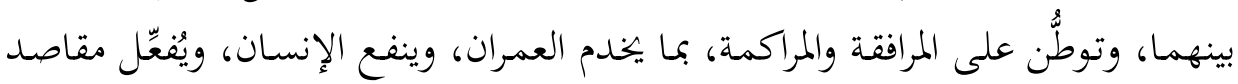
القرآن في ذلك كله.

ويُعبِّر هذا التآلف البيئي عن الإرادة الطوعية الحرة للإنسان، الذي يحب بيئته، ويغار

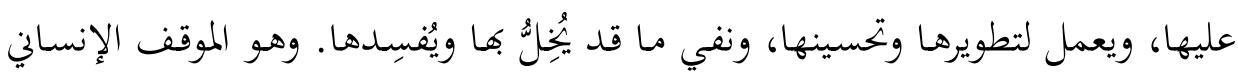

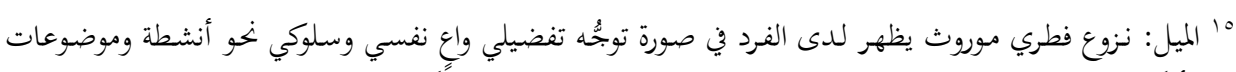

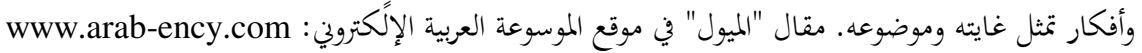


القِيمي الأخلاقي الإيماني مـن البيئة، على خهاف الموقف العدائي منها، الذي يرى أن

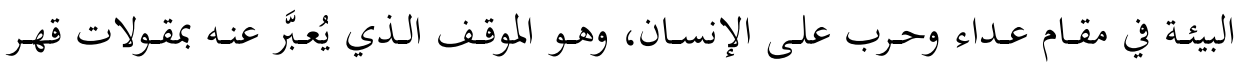

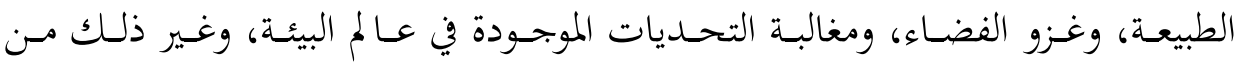

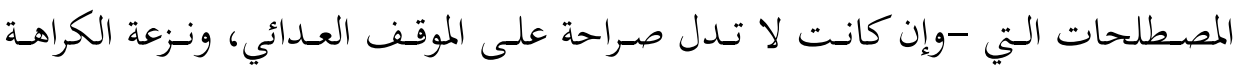
للبيئة- قـد تشـير إلى الموقف الذذي يوصف في حسدِّه الأدنى بأنسه لا يرتكز على قاعـدة التآلف مع البيئة، والاستجابة للميل الطبيعي بتاهيا.

\section{ا ـ أوجه مقاصدية القرآن في التآلف مع البيئة:}

لمذه المقاصدية شواهد كثيرة تُفَهَم وتُستخلَص من بحموع النظر والتحقيق من مظان

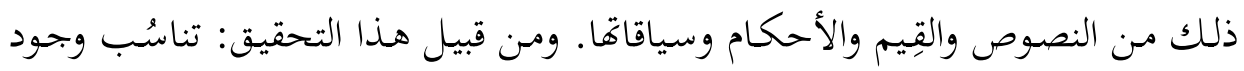

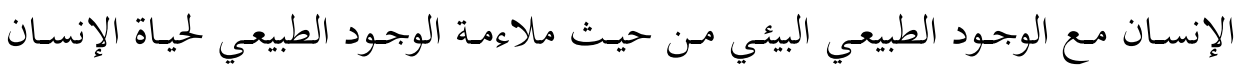

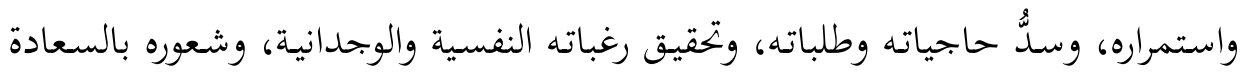

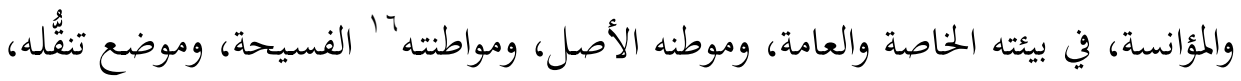
ومأوى حاله، ومستقر أوضاعه وأملاكه وأعماله.

ويكمسن هـا التناسُب في بحموع بحالاته الفرديـة، والجماعية، والجسـدية، والنفسية، والصحية، والغذائية، والمادية، والترفيهية؛ وفي العلوم، والفنون، والحضارة، والعمران. فكل

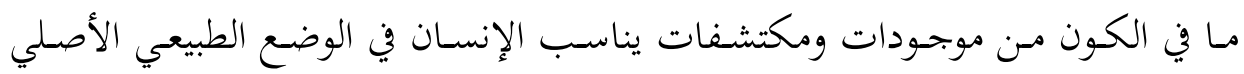

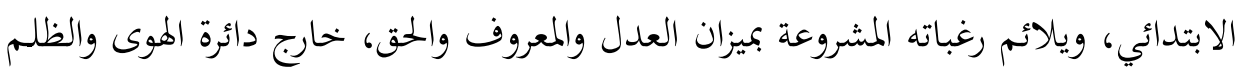
والمنكر والباطل.

"1 هي عبارة عن بحموعة من الحقوق والواجبات، يتمتع بها، ويلتزم بها في الوقت ذاته" كل طرف من أطراف هذه. العلاقة." انظر:

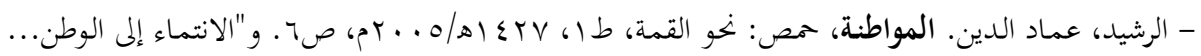

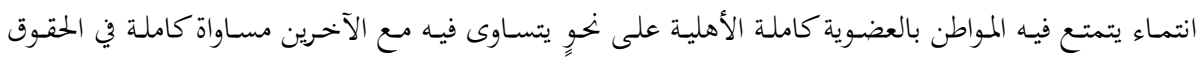

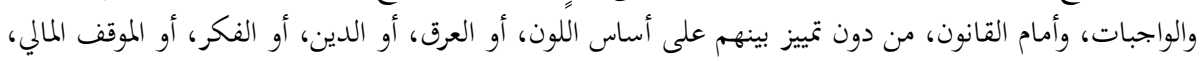

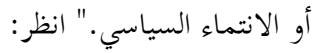

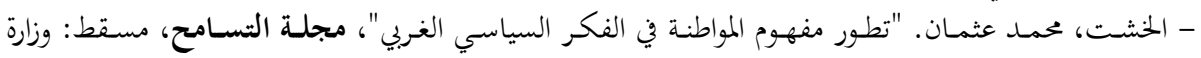

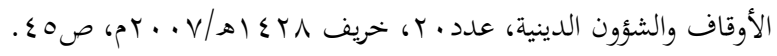




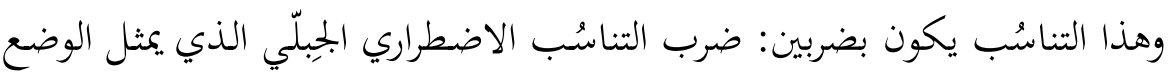

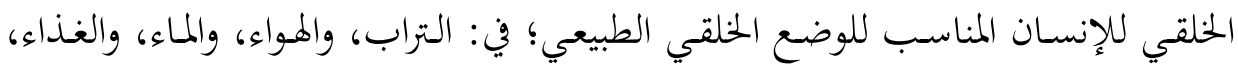

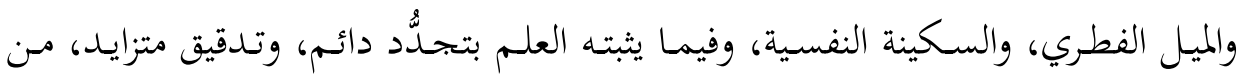

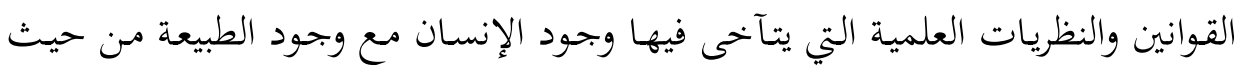
طبيعة الخلق الإنساني وحقيقة الحلق الطبيعي، ومن حيث المشترك التربات الترابي والمائي والهوائي بينهما.

ومقصد القرآن في هـذا التناسُبـ هو بحمـوع مـا يترتب عليه مـ الحقائق العلمية

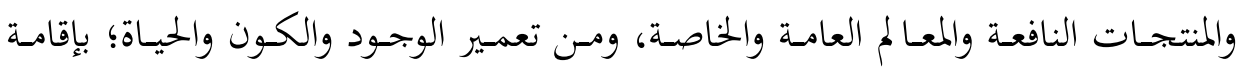

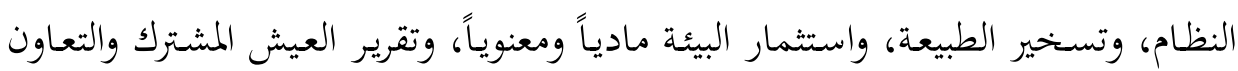
السلمي والمدني بين سائر مكونات الوجود الإنساني.

وما يُبنى على هذا التناسُب من الاستثمار والاستغلال والتعمير والتأثيث والتحسين

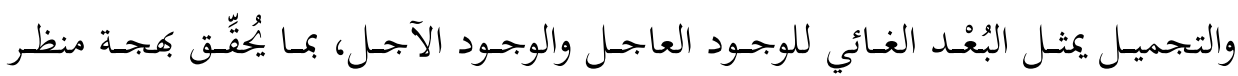

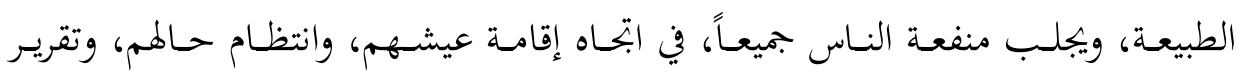

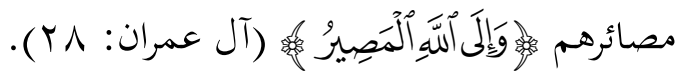
ولـذلك دُعِي الإنسـان إلى اعتبـار هـذا التناسُب موضع التـآلف والتعاون، وأرضـية

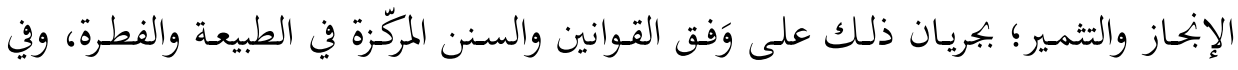

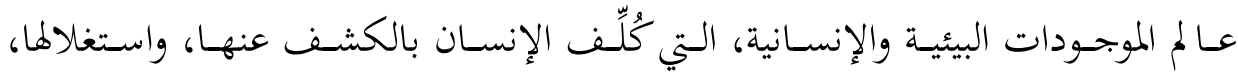

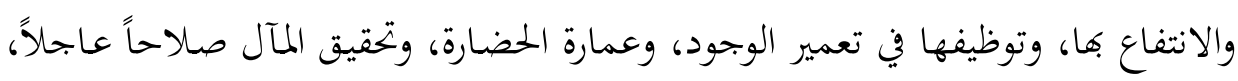

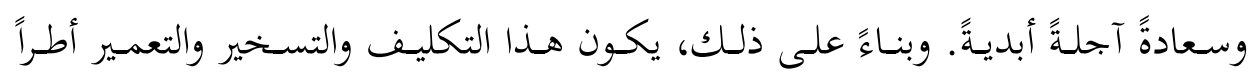

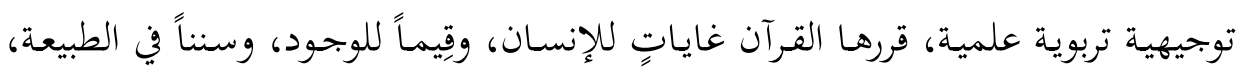
ومعالمُ في الحضارة. 


\section{r. الإخلال بالتناسُب حصادُ مُرٌّ وثمرة خبيثة:}

إحـداث الخلل والاضطراب لنظام التناسُب الإنساني وانتظام الوجود الطبيعي، يعد

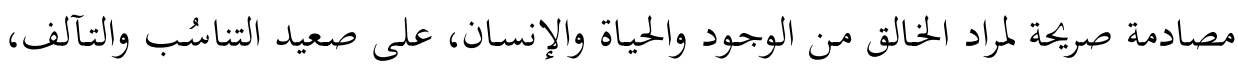

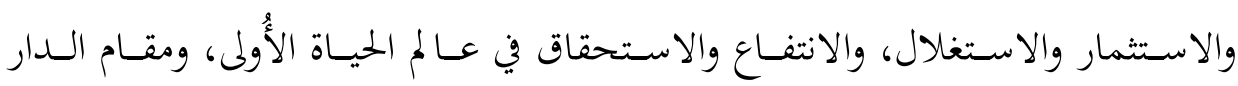
الآخرة.

ويعد أيضاً معارضة شديدة، لا لقِيم الحضارة فحسب، بـل للإنسـان نفسه وفطرته

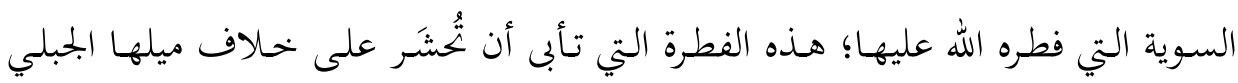

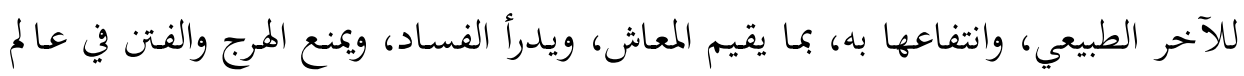
الماديات، والأشياء، والنظم، والفنون، والعلوم.

ويعد هـا الصدام للمراد الإلهي والمصلحة الإنسانية والقِيم الحضـارية فساداً عريضاً

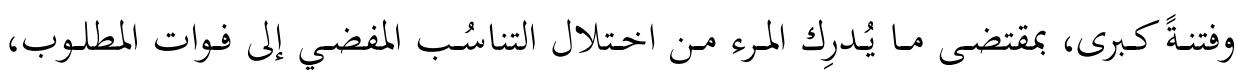

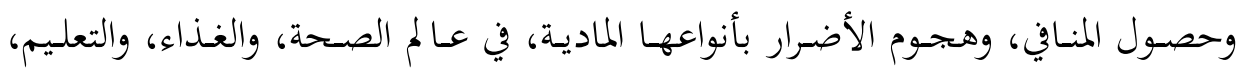

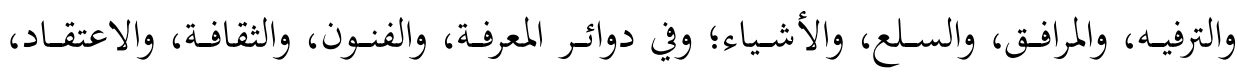

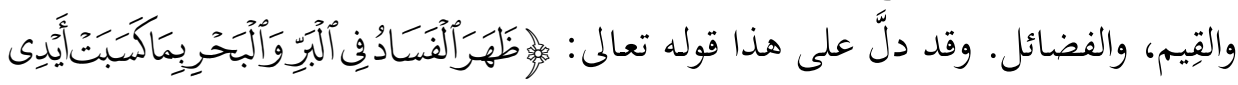

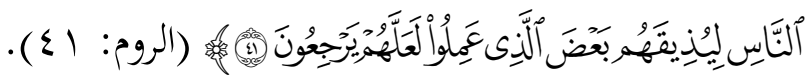

وهو مـا يشير إلى المعنى المقاصدي مـن جهة مصطلح "المفسـدة" التي يجبـ درؤهـا،

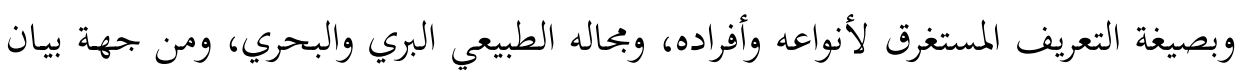

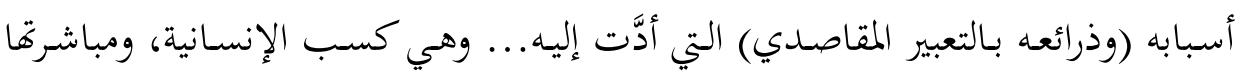

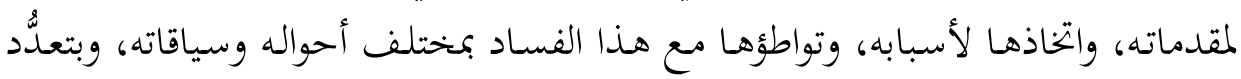

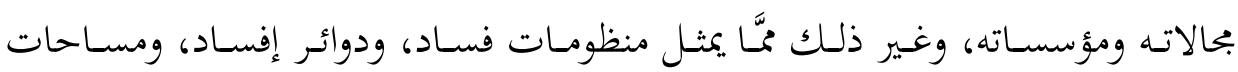
تضليل، وتغليط، وإحباط، وتثبيط.

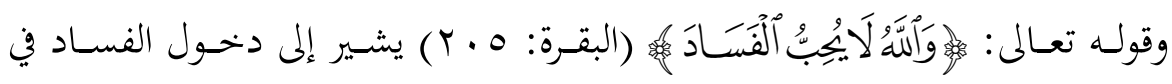

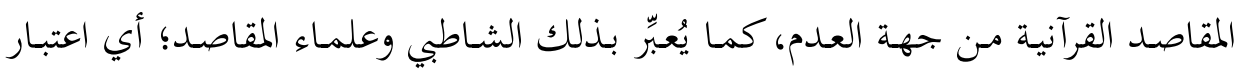

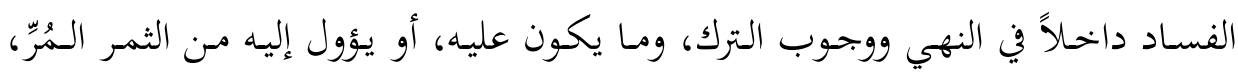




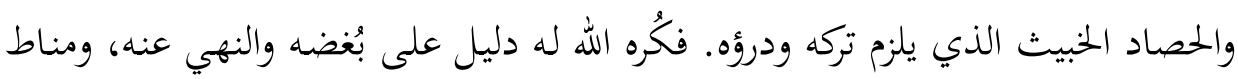
كونه مُضِراً بالإنسان، والطبيعة، والحضارة، والعمران.

والفساد أيضاً مُصادِم لقِيم الانتفاع بالمدخرات والسنن، وحقيقة التناسُب واستثماره،

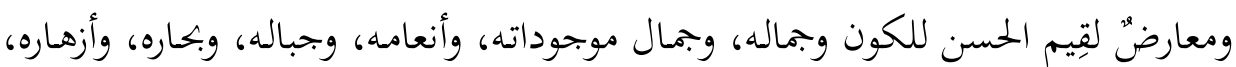
وأهماره.

وما تؤول إليه الطبيعة في أحيان كثيرة من الدمار والتشويه، هو بفعل الإنسان خارج

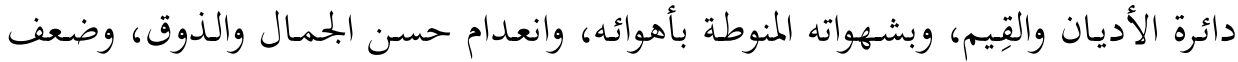

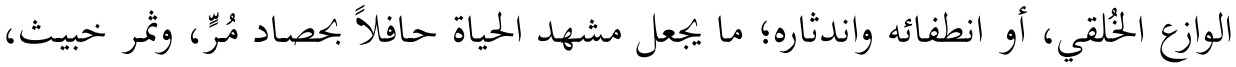
وتنازُع، وتقاثُل.

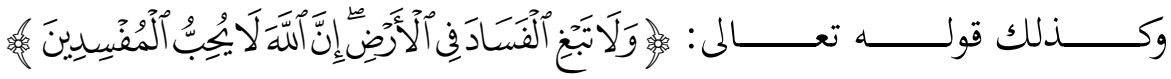

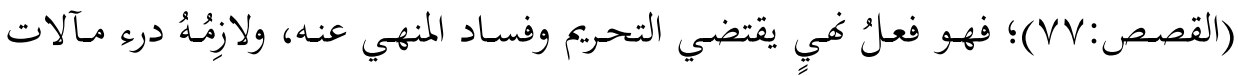

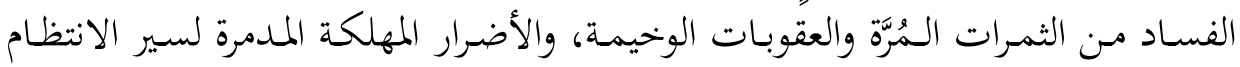

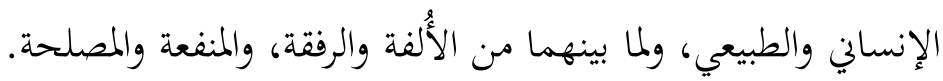

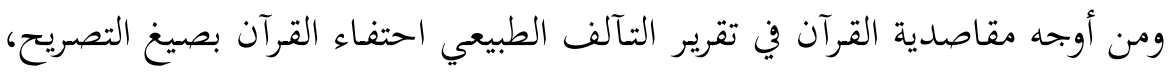

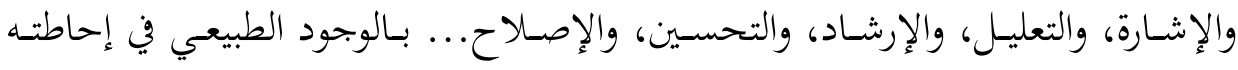

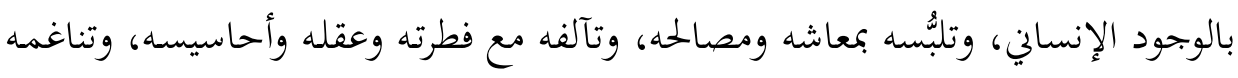

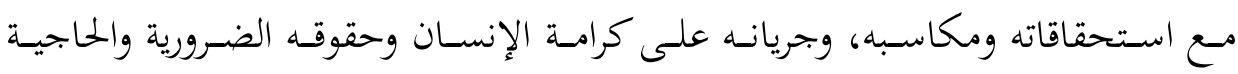
والتحسينية، وغير ذلك.

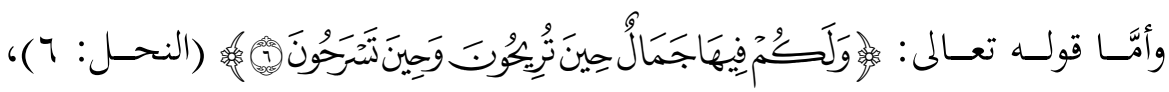
فيشير إلى العلاقة الفطرية الطبيعية الوظيفية بين الإنسان والطبيعة والحضارة؛ إذ أوردت الحتان

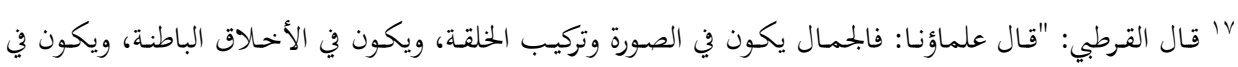

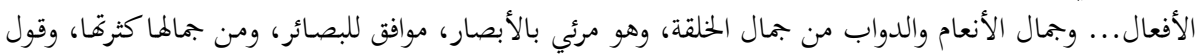

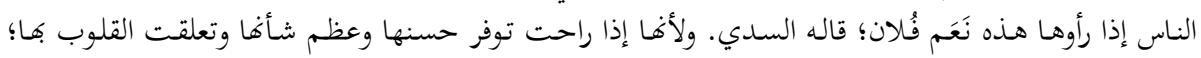

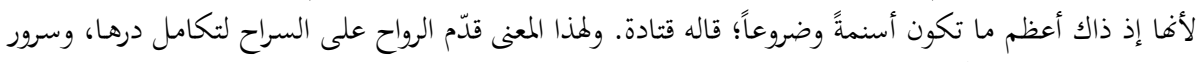

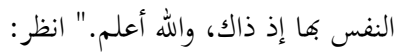

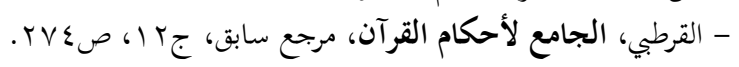




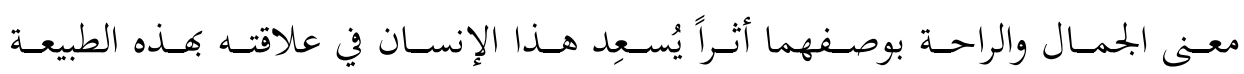
والموجودات الحيوانية تحديداً.

ولا شـك في أن رغبة الجمَّال والراحـة والمتعة، وتحقيق الدفء والنفع، وترتيب الأتر، وتحصيل الثمر، وبناء العمارة الحضارية، وكسب العمران المادي والمعنوي والجمعي في دوائر العلوم والفنون، والصنائع والحـرف، والمهارات والملكات، والنظم والمنظومـات؛ كل ذلك

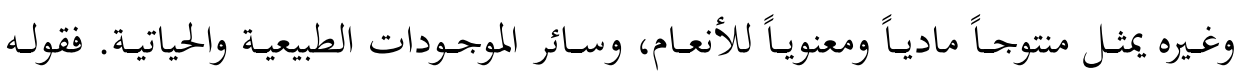

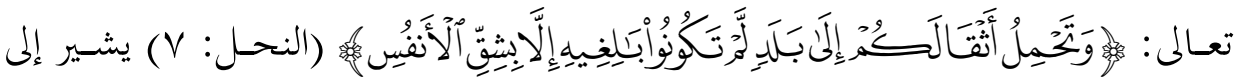
نقل البضائع والأشخاص والمعلومات والسلع والأشياء، بموجب هذه الناقلات والدواب، التي تعد نعمة وبكجة، ووسيلة لتخفيف الأعباء والأثقال.

ومـن أوجهـ الأبعاد المقاصدية القرآنية في التـآلف البيئي، الوجـه المتعلق بالبيئة؛ إطـاراً للإبنهاز الإنسـاني، ومسـرحاً للأعمـال والصـنائع والابتكـارات، ووعـاءً للمنتجـات الماديـة والمعنوية والثقافية والمحتمعيـة وغيرها، مَّا يفتقر إليها الناس في نظام معاشهمه، ومقتضيات

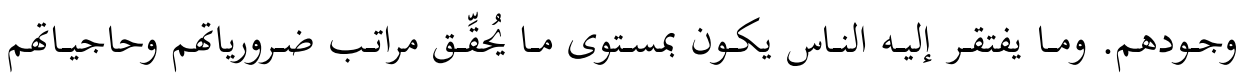
وتحسيناةهم، ومصالحهم في مختلف أوضـاع الدولة، وإمكانياتها، وتحـدياتها، وهـو مـا يمثل موضع التفسير المقاصدي القرآي الذي يتناول هذه المراتب على صعيد البيئة والمدخرات الطبيعية والمنجزات الحضارية الخادمة لذلك كله.

ولا ينبغي أن يُنظَر إلى البيئة على أهـا بجمري في بحال مـا هـو تحسيني تكميلي يُـرَج ضـمن مرتبـة المقاصد التحسينية فحسبب، بـل بتحري بمستوى مراتب الحـاجي والضـروري بحسب اعتبار ذلك وسياقه، وما يؤول إليه من حفظ الضروريات والحاجيات. فبيئة الغذاء والماء والهواء والدواء بيئة ضرورية في بجال ما هو ضروري، يتوقف عليه وجـود الإنسان، وهي البيئة التي تمثلها التربة الطبيعية، واللمدمة اللازمة، والظروف المواتية (علمياً، وسُننياً، وحضارياً) التي تقيم البيئة السوية المنتجة لما هو ضروري وحاجي وهكذا.

والقـرآن يشـير في نَظْمه الجـامع إلى البيئة بالاعتبـار الضـروري والحـاجي، ويشسير إليها أيضـاً بالاعتبـار التحسـيني الكمـالي.... وهـو مـا استقر في هـذا النَّظم مـن تنصسيص على 


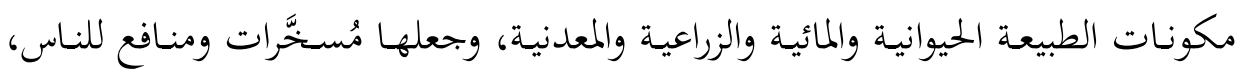
ومحاصسيل للحضـارة والعمـران بمقتضى ذلـك التسـخير، وتداعياتـه على مستوى تطـوير

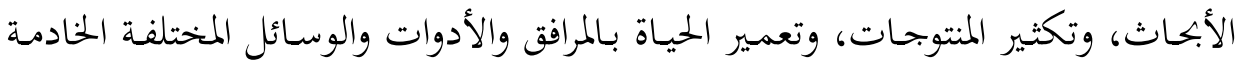
لمظهر البهجة، وظاهرة السعادة، واستمرار العطاء، وانتشار الرخاء.

ولا شك في أن هذا الأمر يُعزّز القدرات الإنسانية على بتحاوز التحدي، ويفضي إلى

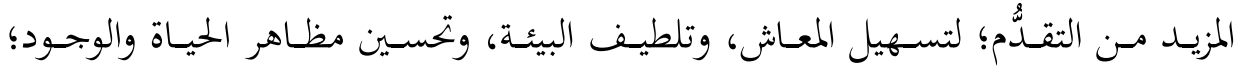
بالتآلف مـع البيئة وحسن استثمارها، لا بخصومتها والرغبـة في الانتصـار عليها وغلبتها ونها وقهرها، بما قد يُغذِّي حالة كراهيتها، والإضرار بها، والانتقام منها.

ومن النظر الفسيح في تآلف الإنسان مع بيئته، تآلفه مع كل ما يحيط به وبكياته من

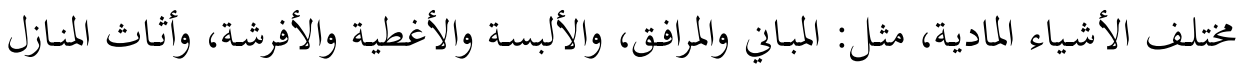

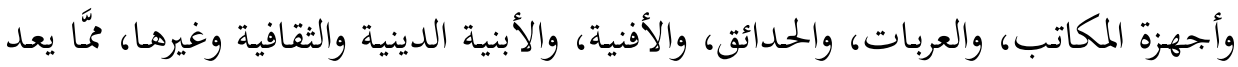

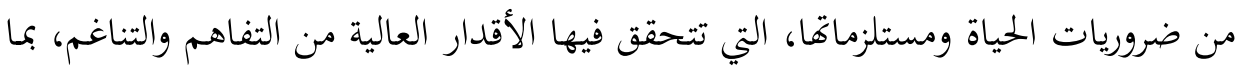

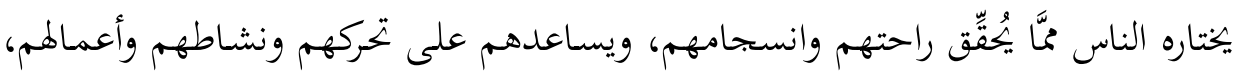
ويستجيب لمعتقداتهم وتمثلاهمم في الدين والعادة والعرف، ويُسهِم في رواج السلع، وتطور

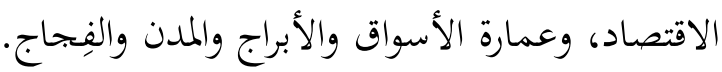

\section{ب. التدهور البيئي مُصادِمٌ لمقاصد القرآن، ومُفوّّت لمطلوب العمران:}

للقرآن الكريم أحكام بيئية كلية وجزئية، ثابتة بنظرٍ فسيح لعموم القرآن وخصوصه،

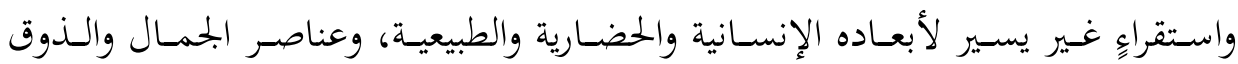

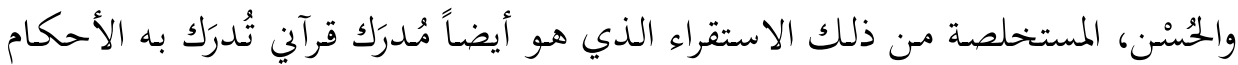
الكلية والمقاصدية القرآنية العظيمة.

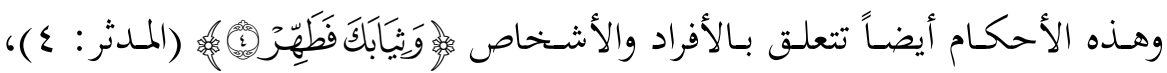

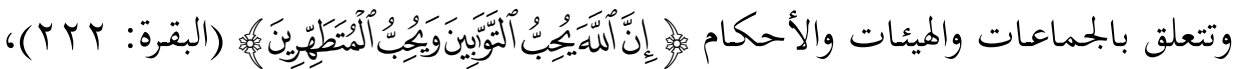

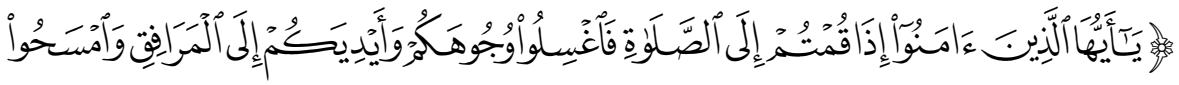




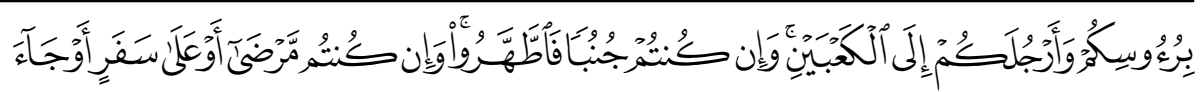

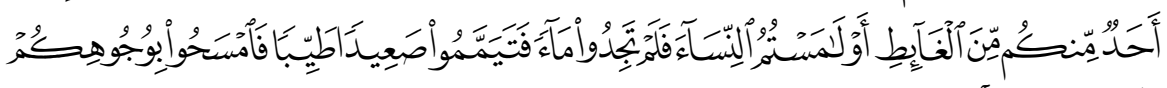

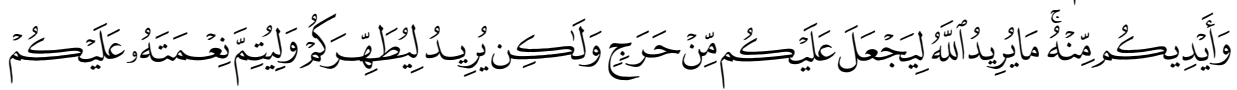

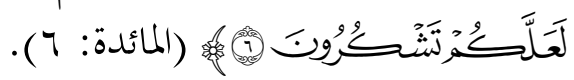

ومعلـوم أن هـذه الأحكام تقـوم على مقاصـدها المركـوزة فيهـا؛ فالأحكـام مشـروعة لمصـالح العبـاد في المعاش والمعاد، وهـو مـا يُؤسِّس لضربين مـن المقاصدـ؛ المقاصد الجزئيسة، والمقاصد الكلية، التي هي موضوع الطهارة -على سبيل التمثيل، وبوصفها ضرباً مُهِمّاً

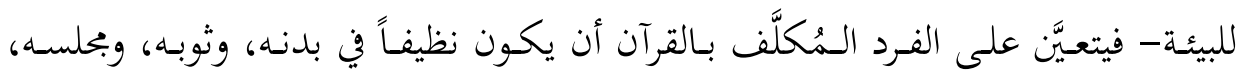

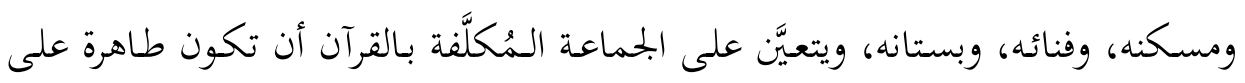

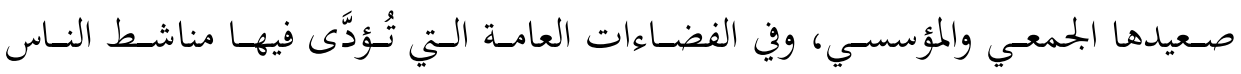

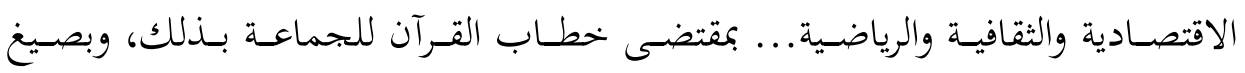
الجماعة الدالة على الفعل الجمعي المؤسس المنتظم، بموجب الإرشاد إلى الطهارة الجماعية

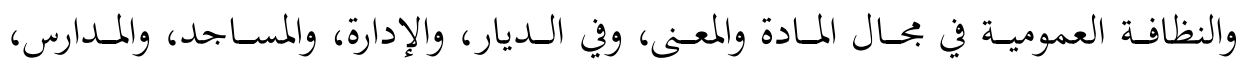
والمختمع، والحياة العامة.

وما آلت إليه أحوال بيئية كثيرة في بلادنا وعالمنا، من حيث حجم التدهور والفوضى

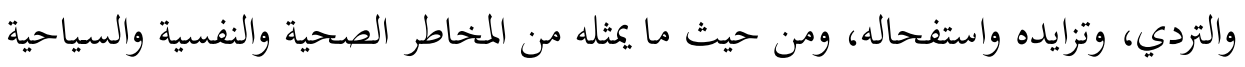

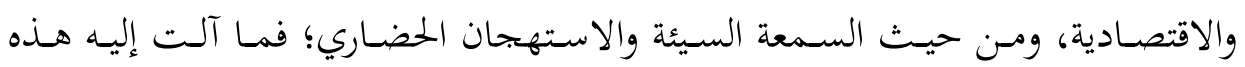

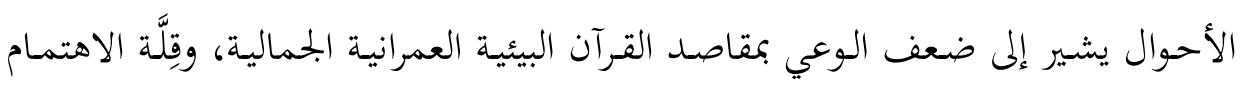

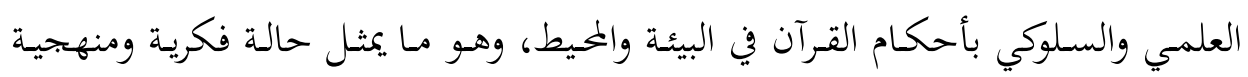

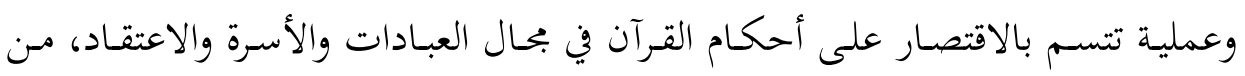

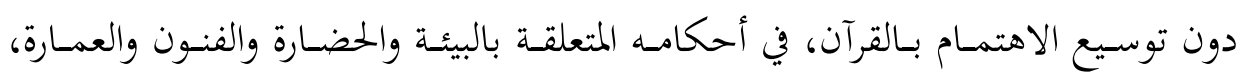

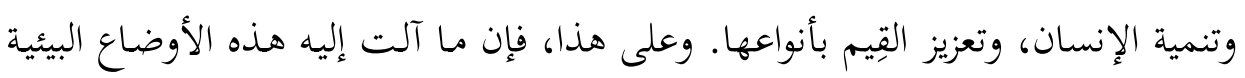

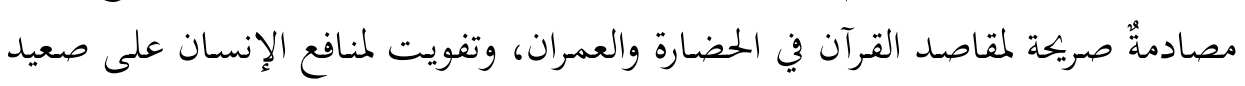
ذلك كله. 
تناول هذا البحث مستويات التواصُل بين مقاصد القرآن وقِيم الإنسان الحضارية،

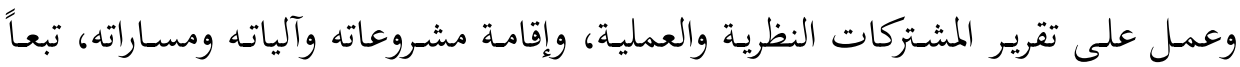

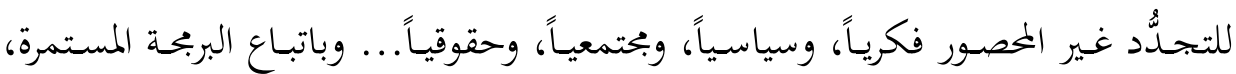

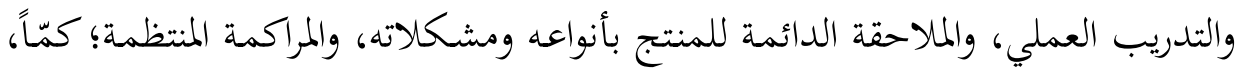

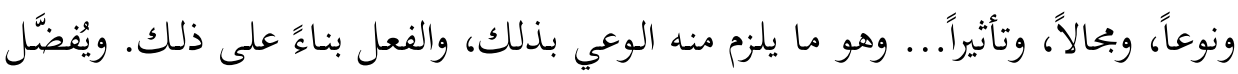

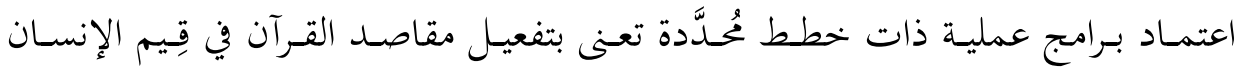

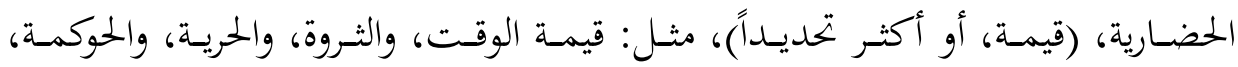

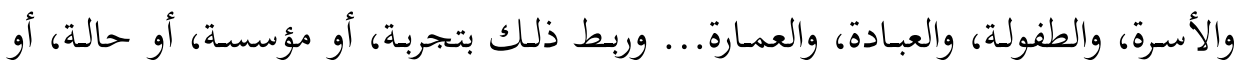

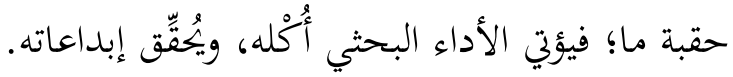
فبين مقاصد القرآن وقِيم الإنسان الحضارية تدانُّل وتواصُّل مـن جهـة المضامين والحقائق، لكلِّ من هذه المقاصد وتلك القِيم، فيما يتعلق بالإنسان وأبعاده ووظائفه في تحقيق ذلك فهماً نظرياً، وأداءً سلوكياً، ومشروعاً حضارياً. وهذه المقاصد تمثل قِيماً إنسانيةً، وتحقيقها يكون انطلاقاً من الوعي بالقرآن مصدرَّ

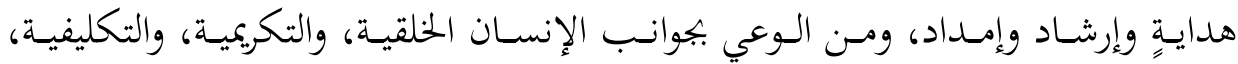

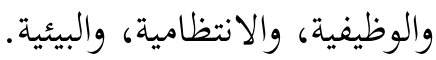

وقد انتهى البحث إلى جملة من التوصيات والتساؤلات، يمكن إجمالها فيما يأتي: - وصل المعرفة النظرية بواقع الحال، وبرامج التخطيط والتدريب وبناء الذات الواعية

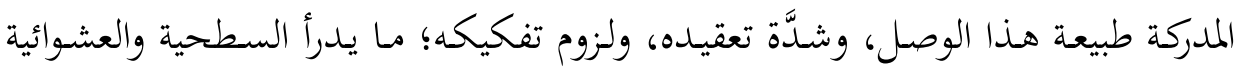
والدغمائية في الطرح، والتشخيص، والتحليل، والاستنتاج، والتوظيف، والتثمير. - كيف يمكن ربط آفاق مقاصد القرآن في بناء العمران بفعالية الإنسان، ومنظومة

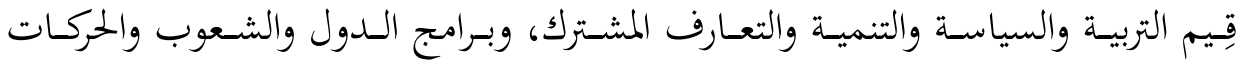

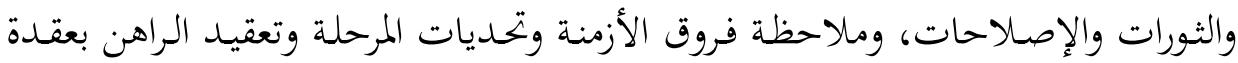


نفسية عامـة ليس لها مـن دون الله كاشفة؟ ومتتى يكون ذلك؟ وما الأسباب الموجبـة له؟ وأين يمكن تحقيقه؟

- كيف يمكن الإنتاج بالمقاصد والقِيم، وبأدوات الإنتاج (مسارات الفهم والإفهام، ومناهج الحكم والحكمة)، وبإمكانيات الإنتاج مع تأمل تحدياته وتعقيداته؟ - الاهتـداء بالنصـوص والثوابـت، وتهـيب النفـوس والوقائع؛ للخلـوص بالعـالم مـن قِيمــه المبتخوسـة، واسـترجاع مقاصسـه المخطوفـة، المجخرَجـة مـن أطرهـا الموضـوعية المعرفيـة، وعمقها الحضاري الإنساني، وسياقها الحالي المبعاوِد لافتكاك القِيم، وانتزاع المقاصد. ولا شـك في أن ذوي المـروءة سينتصسرون قِيمـاً ومقاصــَ؛ لأغهـم بجبولـون بـالفطرة، ومعـدلون بـالخلق. أمَّـا معـاودو الظلـم ومزاولـو الجــرم، في حـق القِيم والحضـارة والمقاصـد

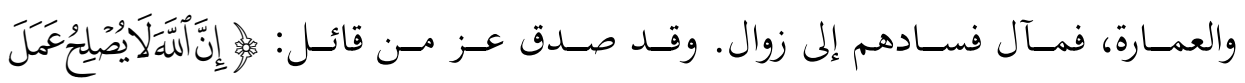

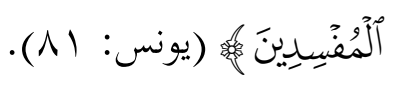

